\title{
White spots on enamel: Treatment protocol by superficial or deep infiltration (part 2)
}

\section{Taches blanches de l'émail : protocole de traitement par infiltration superficielle ou en profondeur (partie 2)}

\author{
Jean-Pierre ATTAL ${ }^{\mathrm{a},{ }^{, b, c},}$, Anthony ATLAN ${ }^{\mathrm{a}, \mathrm{b}, \mathrm{c}}$, Maud DENIS ${ }^{\mathrm{a}, \mathrm{b}, \mathrm{c}}$, Elsa VENNAT $^{\mathrm{d}}$, \\ Gilles TIRLET ${ }^{\mathrm{b}, \mathrm{c}}$ \\ ${ }^{a}$ Unité de recherches biomatériaux innovation et interfaces (URB2i), faculté de chirurgie \\ dentaire, Paris Descartes, 1, rue Maurice-Arnoux, 92120 Montrouge, France \\ ${ }^{\mathrm{b}}$ Faculté de chirurgie dentaire, 1, rue Maurice-Arnoux, 92120 Montrouge, France \\ ${ }^{\mathrm{c}}$ Hôpital Charles-Foix, 7, avenue de la République, 94205 Ivry-sur-Seine, France \\ ${ }^{\mathrm{d}}$ École centrale Paris, laboratoire MSSMat, grande voie des Vignes, 92295 Châtenay-Malabry, \\ France
}

Available online: 3 February 2014 / Disponible en ligne : 3 février 2014

\section{Summary}

In this 2nd part, the current treatment of white spot lesions by erosion/infiltration is presented, beginning with a reminder of the principle of superficial infiltration, which enables most early carious lesions, fluorosis and post-traumatic lesions to be treated. However, this technique has met with frequent failures in cases of MIH or deep lesions of traumatic origin or those associated with fluorosis. For this reason a new deep infiltration technique is proposed: thanks to its global treatment concept, this enables all white spots to be treated. The place of whitening in these treatment options is discussed, with explanations of the main reasons for its failures.

(C) 2014 CEO. Published by Elsevier Masson SAS. All rights reserved

\section{Key-words}

- MIH.

- Fluorosis.

- White spot.

- Traumatic hypomineralization.

- Superficial infiltration.

- Deep infiltration.

\section{Résumé}

Dans cette $2^{e}$ partie, nous présenterons le traitement actuel des taches blanches par le procédé d'érosion/infiltration. Nous rappellerons le principe de l'infiltration superficielle qui permet de traiter la plupart des lésions carieuses débutantes, des fluoroses et des lésions post-traumatiques. Cette technique présentait de nombreux échecs dans les cas de $\mathrm{MIH}$ ou de lésions profondes d'origine traumatique ou liées à une fluorose. C'est pourquoi nous ferons une nouvelle proposition, l'infiltration en profondeur, qui permet de traiter, grâce à un concept de traitement global, toutes les taches blanches. Nous discuterons la place de l'éclaircissement dans ces traitements et nous expliquerons les raisons des principaux échecs. (C) 2014 CEO. Édité par Elsevier Masson SAS. Tous droits réservés

\section{Mots-clés}

- $\mathrm{MIH}$.

- Fluoroses.

- Taches blanches.

- Hypominéralisation traumatique.

- Infiltration superficielle.

- Infiltration en profondeur. 
Erosion/infiltration is a technique that was proposed when a new product (Icon-DMG), designed to halt caries in the posterior segment, was launched on the market [1]. Thanks to its first stage, involving superficial demineralization by application of a $15 \%$ solution of hydrochloric acid, this technique opens up access to the hypomineralized lesion; then, in a second stage, an extremely fluid resin is infiltrated into the body of the lesion.

Clinical studies have confirmed the efficacy of the technique for this indication [2,3] and, more recently, its ease of integration into clinical practice [4]. Several consequences of this infiltration have been highlighted: in particular, an increase in the mechanical resistance of the demineralized enamel $[5,6]$ and also an increase in the resistance of healthy enamel to demineralization [7]. In addition, since bonding to infiltrated enamel provides good adhesion [8,9], applications in orthodontics have been proposed [10]. One study even concludes that resin infiltration into demineralized enamel reduces the risk of enamel fracture when brackets are debonded [11].

Another consequence of this infiltration is that it masks the white spot on the enamel that characterizes the initial carious lesion. The white spot is in fact the result of a complex optical phenomenon [12] whereby an optical maze formed within the lesion contributes to the reflection of incident light. Infiltration of the pores of the lesion with a resin whose refractive index (1.52) is close to that of healthy enamel (1.62) improves the transmission of photons through the hypomineralized enamel and restores its translucence [13].

This explains why the inventors of the technique have suggested its use for masking white spots in enamel caused by early-stage caries. In vitro studies have clearly shown these optical modifications of hypomineralized lesions [13,14], giving better results than those obtained by applications of amorphous calcium phosphate or fluorine solutions [14,15]. Moreover a preliminary clinical study has demonstrated partial success in the masking of post-orthodontic white spot lesions [16]. We first proposed [17] an extension of the indications to include fluorosis and traumatic lesions since, in these cases, as in early-stage caries, the lesion involves the external third of the enamel [12]. Then, through a series of case studies, we showed that the treatment remained effective after 2 years' follow-up [18]. This technique, the efficacy of which has just received fresh confirmation [19], remains perfectly relevant, and can be referred to as superficial infiltration.

However, in the case of white spots involving deep lesions of the enamel - Molar Incisor Hypomineralization (MIH) or certain types of hypomineralization of traumatic origin, or even severe cases of fluorosis - no solution has yet been proposed. We have therefore developed the technique thanks to what we have called deep infiltration [20].

The aim of this article is to present a clinical example of superficial infiltration and then to describe the new concept
L'érosion/infiltration est une technique qui a été proposée, à l'occasion de la commercialisation d'un nouveau produit (Icon-DMG), pour stopper le processus carieux dans le secteur postérieur [1]. Cette technique consiste, grâce à une première étape de déminéralisation superficielle réalisée avec une solution d'acide chlorhydrique à $15 \%$, à atteindre la lésion d'hypominéralisation ; puis dans une $2^{\mathrm{e}}$ étape à venir infiltrer le corps de la lésion par une résine très fluide.

Les études cliniques montrent l'efficacité de cette technique pour cette indication $[2,3]$ et, plus récemment, sa bonne intégration dans l'exercice clinique [4]. Plusieurs conséquences de cette infiltration ont été mises en évidence, notamment une augmentation de la résistance mécanique de l'émail déminéralisé $[5,6]$ ainsi qu'une augmentation de la résistance à la déminéralisation de l'émail sain [7]. Par ailleurs, le collage sur l'émail infiltré étant de bonne qualité [8,9], des applications au niveau orthodontique ont été avancées [10]. Une étude conclut même que l'infiltration de résine au niveau de l'émail déminéralisé diminue le risque de fracture amélaire à la dépose du bracket [11].

Une autre conséquence de cette infiltration réside dans le masquage de la tache blanche de l'émail, caractéristique de la lésion carieuse initiale. En effet, la tache blanche résulte d'un phénomène optique complexe [12] qui, par le jeu d'un labyrinthe optique au sein de la lésion, contribue à réfléchir la lumière incidente. En infiltrant les porosités de la lésion par une résine d'un indice de réfraction proche $(1,52)$ de celui de l'émail sain $(1,62)$, on améliore la transmission des photons lumineux à travers l'émail hypominéralisé et on rend à l'émail son aspect translucide [13].

C'est pourquoi les inventeurs de la technique l'ont proposée pour masquer les taches blanches de l'émail liées aux caries débutantes. Des études in vitro ont bien mis en évidence ces modifications optiques des lésions hypominéralisées [13,14] avec un meilleur résultat que celui que nous pouvons obtenir avec des applications de phosphate de calcium amorphe ou de solutions de fluor $[14,15]$. Une première étude clinique a d'ailleurs mis en évidence un succès partiel dans le cadre du masquage des taches blanches postorthodontiques [16]. Dans un premier temps [17], nous avons proposé d'étendre cette indication aux fluoroses et aux lésions d'origine traumatique car la lésion intéresse, comme la carie débutante, le tiers externe de l'émail [12]. Puis nous avons montré à l'aide d'une série de cas que ce traitement était efficace après 2 ans de recul [18]. Cette technique, qui vient de recevoir une nouvelle confirmation de son efficacité [19], reste toujours d'actualité et peut être nommée : infiltration superficielle.

Toutefois dans le cas des taches de l'émail qui intéressent les lésions profondes - les molaire incisive hypominéralisation $(\mathrm{MIH})$ ou certaines hypominéralisations d'origine traumatique ou même fluoroses sévères - aucune solution n'était jusqu'alors proposée. Nous avons alors fait évoluer la technique grâce à ce que nous avons appelé l'infiltration en profondeur [20].

Le but de cet article est de présenter un exemple clinique d'infiltration superficielle puis de décrire le nouveau concept 
of deep infiltration. It will be seen that this makes it possible to treat all enamel lesions effectively, whatever their etiology. Since these lesions are often colored, we shall also discuss the role of whitening.

\section{Superficial infiltration}

Figs. 1-8 present a clinical case of masking by superficial infiltration of a white spot lesion caused by hypomineralization of traumatic origin.

\section{Deep infiltration}

In our first contribution [17] describing superficial infiltration we limited application of the erosion/infiltration technique to cases which required no dental preparation, such as earlystage caries, most types of mild fluorosis and hypomineralization resulting from superficial traumatic lesions [12]. But the technique as presented resulted in failures in many cases: d'infiltration en profondeur. Nous verrons que ce dernier nous permet de traiter avec efficacité toutes les taches blanches de l'émail quelle que soit leur étiologie. Comme les taches sont souvent colorées, nous indiquerons le rôle de l'éclaircissement.

\section{Infiltration superficielle}

Les fig. 1-8 présentent un cas clinique de masquage par infiltration superficielle d'une tache blanche sur une hypominéralisation d'origine traumatique.

\section{Infiltration en profondeur}

Dans notre première contribution [17] qui décrivait l'infiltration superficielle, nous avions réservé la technique d'érosion/infiltration aux cas qui ne nécessitaient aucune préparation dentaire. C'est le cas des caries débutantes, de la plupart des fluoroses légères et des hypominéralisations d'origine traumatique superficielles [12]. Mais la technique présentée aboutissait à des échecs dans de nombreux cas :

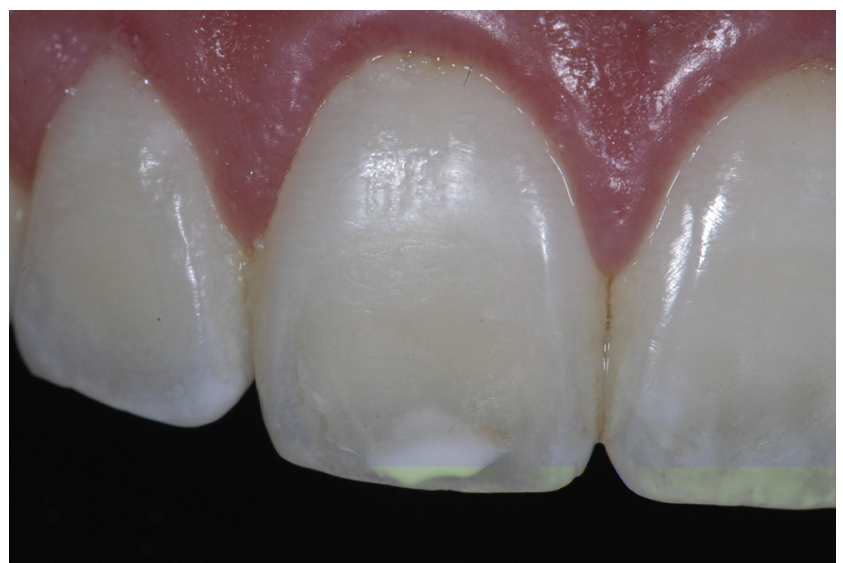

Fig. 1: A young adult who consulted to see whether it was possible to treat the white spot on the upper right central incisor. No involvement of the first molars (this is not a case of $\mathrm{MIH}$ ), no symmetrical involvement (this is not fluorosis), no demineralization of carious origin (unusual position, accessibility to brushing). By elimination we therefore suggest a diagnosis of hypomineralization of traumatic origin. Slight infiltration by extrinsic pigments produces discoloration (brown) on the mesial part of the spot.

Fig. 1 : Jeune adulte qui consulte pour savoir s'il est possible de traiter avec un minimum de mutilation la tache blanche sur son incisive centrale supérieure droite. Pas d'atteinte sur les premières molaires (ce n'est pas une MIH), pas d'atteinte symétrique (ce n'est pas une fluorose), pas de déminéralisation carieuse (position rare, accessibilité au brossage). Par élimination nous posons donc le diagnostic d'hypominéralisation d'origine traumatique. Une petite infiltration de colorants extrinsèques donne un aspect coloré (marron) sur la partie mésiale de la tache. 


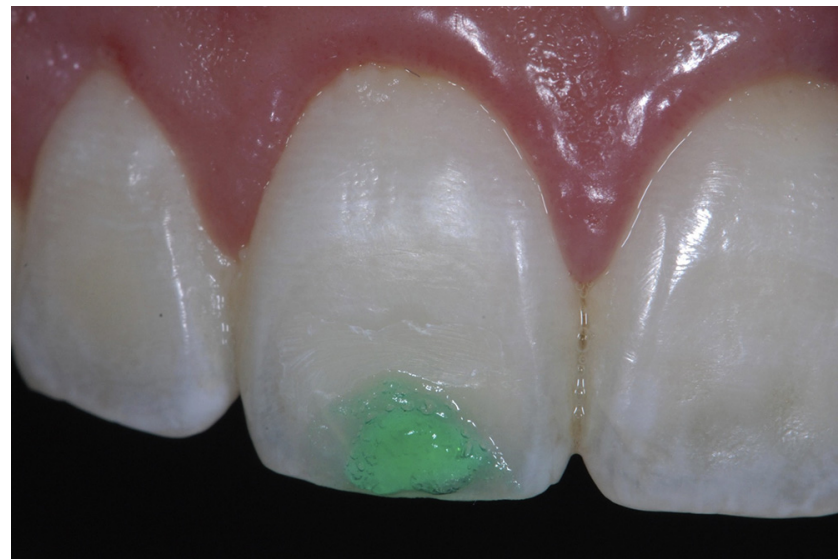

Fig. 2: Application of Icon Etch $(15 \% \mathrm{HCl})$ for 2 minutes. Note here that, since access is easy, surgical protection is provided simply by dry aids on the buccal side and good aspiration.

Fig. 2 : Mise en place de Icon Etch ( $\mathrm{HCl}$ à $15 \%)$ pendant 2 minutes. Notons ici que l'accès étant très facile, le champ opératoire était constitué par des cotons salivaires dans le vestibule et une bonne aspiration chirurgicale.

- cases where lesions originate at the dentino-enamel junction and extend into the enamel, as in MIH. In these cases, during the successive stages of erosion (several applications of HCl), what could be called the "ceiling" of the lesion is not reached. Infiltration takes places on the level of healthy enamel and therefore does not produce a favorable optical effect. This is why treatments of MIH lesions by erosion/infiltration were never, or almost never, successful;
- les cas des lésions qui débutent à la jonction émail/dentine et qui se développent en direction de l'émail comme les $\mathrm{MIH}$. En effet, lors des étapes d'érosion successives (plusieurs passages d'HCl), on n'atteint pas ce que nous pouvons appeler le « plafond » de la lésion. L'infiltration se fait au niveau d'un émail sain et ne produit donc aucun effet optique favorable. C'est pourquoi les traitements par érosion/infiltration des lésions des MIH n'étaient jamais, ou presque jamais, couronnés de succès ;

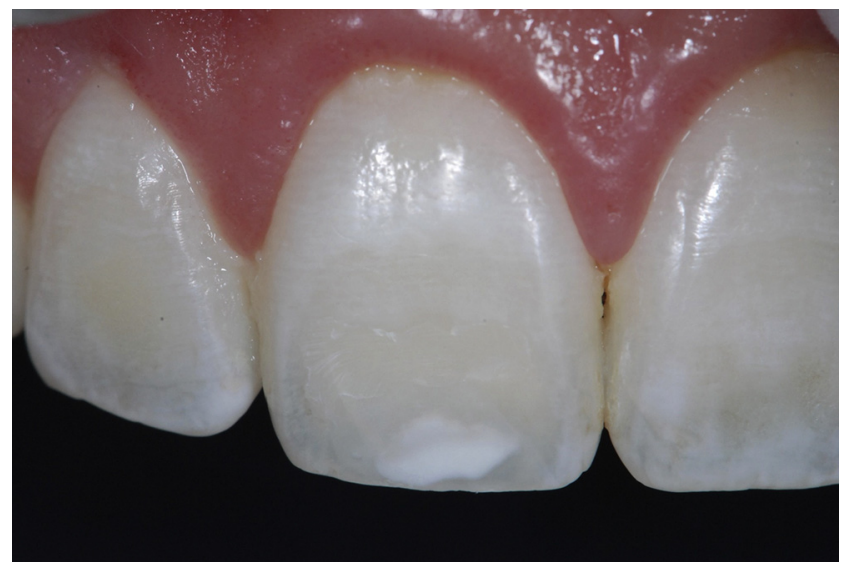

Fig. 3: After rinsing and drying the white spot is still visible. The brown discoloration has disappeared. If it had not disappeared at this stage it would have been useful to treat the tooth surface for 5 minutes with $5 \%$ sodium hypochlorite [21].

Fig. 3 : Après rinçage et séchage, la tache blanche est encore plus visible. La dyschromie marron a disparu. Si elle n'avait pas disparu à ce stade, il aurait été utile de traiter la surface dentaire pendant 5 minutes à l'hypochlorite de sodium à $5 \%$ [21]. 


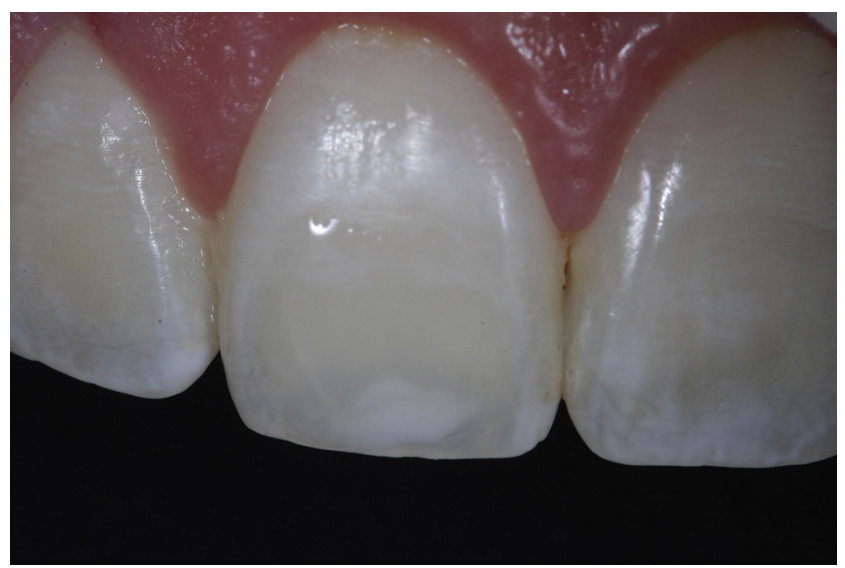

Fig. 4: Drying with alcohol does not reveal masking of the spot. The application of Icon Etch should therefore be repeated (see the section on alcohol as an indicator of the position of the lesion).

Fig. 4 : Le séchage à l'alcool ne permet pas de visualiser un masquage de la tache. II faut donc renouveler l'application d'Icon Etch (voir plus loin dans le chapitre sur l'alcool, indicateur de la position de la lésion).

- cases where the lesion originates at the surface but is in fact very deep, like certain forms of traumatic hypomineralization or severe types of fluorosis. In these cases, the ceiling is quickly reached but only a small part of the lesion is infiltrated (300 to $400 \mu \mathrm{m}$ ) and masking remains insufficient (figs. 9 and 10).

In view of the high level of prevalence of such cases, it was essential to find solutions to overcome these failures. The concept of deep infiltration involves paying a price in the form of mild mutilation of the enamel through preparation by sandblasting or milling so as to ensure that the infiltration can indeed reach the "ceiling" of the lesion in the case of MIH or spread through almost the whole of the lesion if the latter is deep (fluorosis or deep traumatic hypomineralization).
- les cas où la lésion débute en surface mais est très profonde, comme certaines hypominéralisations d'origine traumatique, voire certaines fluoroses sévères. En effet dans ce cas, le plafond est très rapidement atteint mais seule une petite partie de la lésion est infiltrée (sur 300 à $400 \mu \mathrm{m}$ ) et le masquage reste insuffisant (fig. 9 et 10).

Étant donné la prévalence importante de ces cas, il était important d'apporter des solutions à ces échecs. L'idée de l'infiltration en profondeur consiste, en concédant une légère mutilation de l'émail à l'aide d'une préparation par sablage ou par fraisage, à s'assurer que l'infiltration se fait bien au niveau du « plafond » de la lésion dans le cas des MIH ou que l'infiltration se fait bien dans la quasi-totalité de la lésion si cette dernière est profonde (fluorose ou hypominéralisation traumatique profonde).

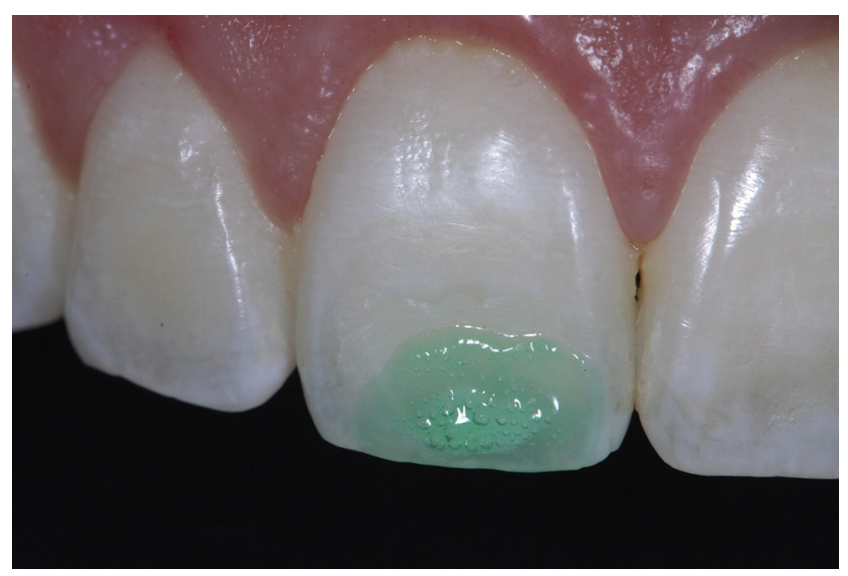

Fig. 5: Second application of Icon Etch.

Fig. 5 : Deuxième application d'Icon Etch. 


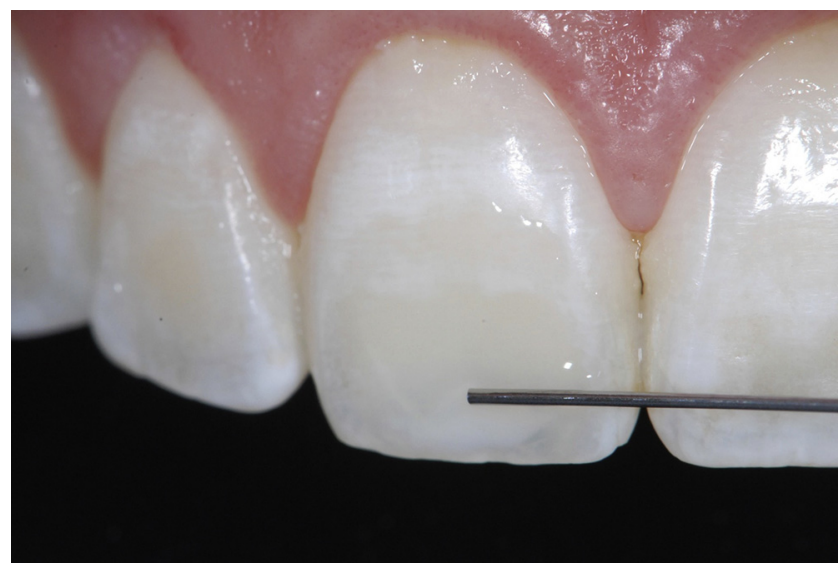

Fig. 6: After rinsing and drying with alcohol, masking of the spot seems favorable. Infiltration by resin should offer still better masking. Infiltration with Icon Infiltrant is therefore performed. If, at this stage, masking following application of alcohol had not been sufficient, a third application of Icon Etch would have been performed. To accelerate the procedure, the acid can be rubbed in for a few seconds using a microbrush or the syringe tip supplied.

Fig. 6 : Après rinçage et séchage à l'alcool, le masquage semble favorable. L'infiltration de la résine devrait améliorer encore le masquage. On décide donc l'infiltration de Icon Infiltrant. Si à ce stade, après le passage de l'alcool, le masquage était insuffisant, nous aurions appliqué une $3^{\mathrm{e}}$ fois Icon Etch. Pour accélérer la procédure on peut envisager de frotter quelques secondes l'acide avec une microbrosse ou l'embout fourni.

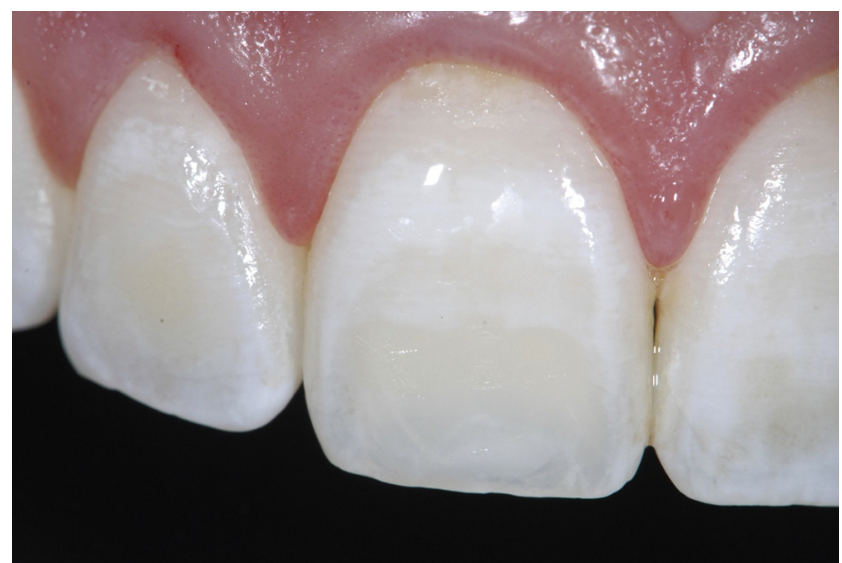

Fig. 7: After the first application of Icon Infiltrant and light-curing for 60 seconds, the spot is well masked.

Fig. 7 : Après la première application d'Icon Infiltrant et une photopolymérisation de 60 secondes, la tache est bien masquée. 


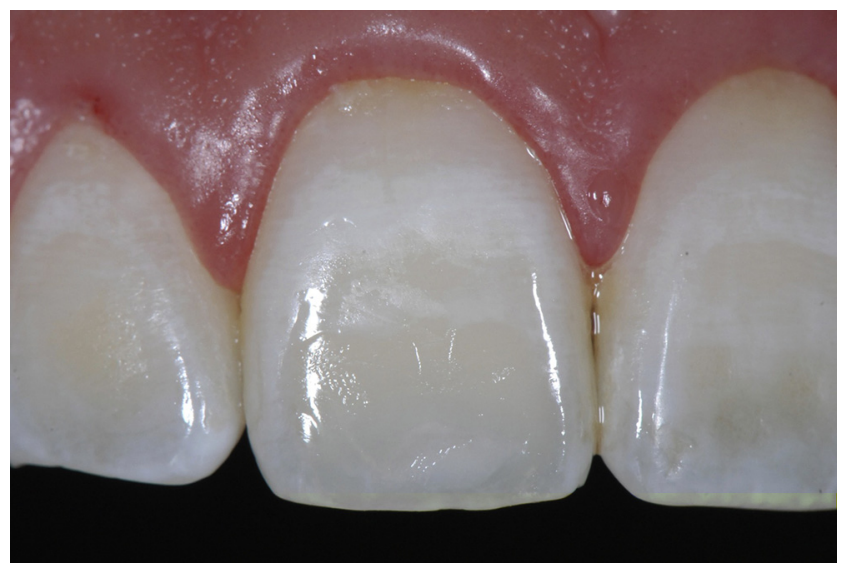

Fig. 8: View after the second application of Icon Infiltrant. It is important to ensure good light-curing of the surface of the lesion after the first infiltration and the recommended second infiltration. In order to limit the layer inhibited by oxygen we recommend, after polishing, the application of glycerin followed by a third light-cure. Polishing seems to be an important parameter to ensure chromatic stability of the resin surface [13].

Fig. 8 : Vue après la deuxième application d'Icon Infiltrant. II faudra veiller à bien photopolymériser la surface de la lésion après la première et après la $2^{\mathrm{e}}$ infiltration recommandée. Afin de limiter la couche inhibée par l'oxygène, nous préconisons, avant polissage, la mise en place de glycérine suivie d'une $3^{\mathrm{e}}$ photopolymérisation. Le polissage semble être un paramètre important de la stabilité chromatique de la résine en surface [13].

In depth, after erosion followed by infiltration, the dental support changes from an opaque white color to the natural translucence of enamel (figs. 11 and 12).

If the hollow left by milling or sandblasting is significant the slight loss of material (of the order of 100 to $300 \mu \mathrm{m}, 500 \mu \mathrm{m}$ at most) can be made up with composite. After light-curing of the infiltrate, the resin will be used as an adhesive support. It is for this reason that glycerin should not be used. Several studies have shown that bonding between the resin infiltrate and composite is of very good quality $[8,22]$.
En profondeur, après l'érosion puis l'infiltration, le support dentaire passe de la couleur blanche opaque à la translucidité naturelle de l'émail (fig. 11 et 12).

Si la concavité, conséquence du fraisage ou du sablage, est significative, alors on comble au composite la légère perte de substance consentie (de l'ordre de 100 à $300 \mu \mathrm{m}$, au maximum $500 \mu \mathrm{m}$ ). Après la photopolymérisation de l'infiltrant, nous allons nous servir de cette résine comme d'un adhésif. C'est pourquoi il ne faudra pas mettre en place de la glycérine. Plusieurs études ont montré que la liaison de la résine d'infiltration et d'un composite était de très bonne qualité $[8,22]$.

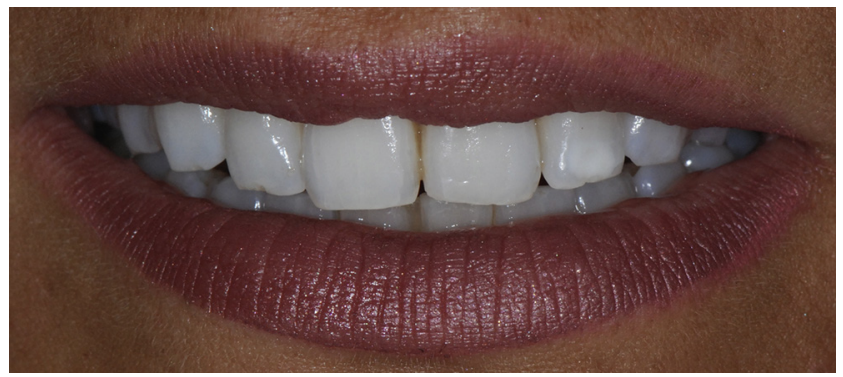

Fig. 9: White spot of traumatic origin on 22 .

Fig. 9 : Tache blanche d'origine traumatique sur 22. 


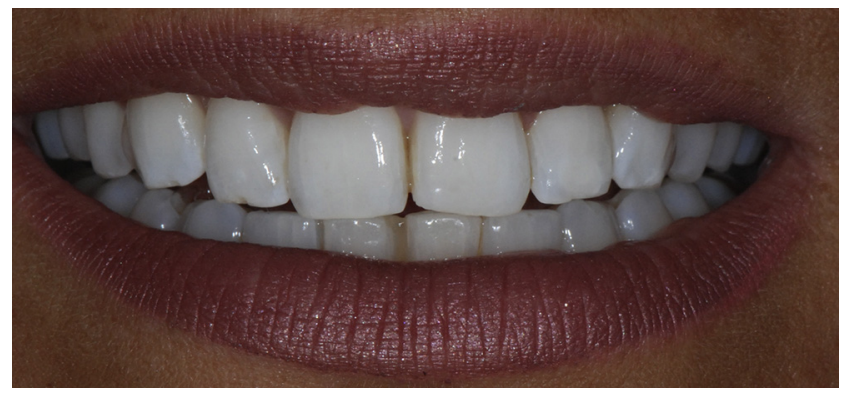

Fig. 10: After superficial infiltration, masking remains partial but satisfactory.

Fig. 10 : Après infiltration superficielle, le masquage, bien que satisfaisant, reste partiel.

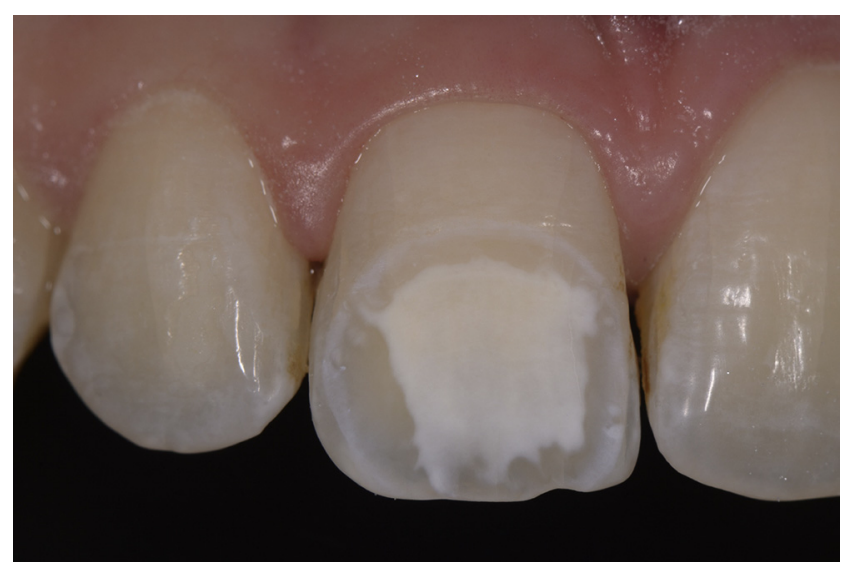

Fig. 11: After elimination of 0.2 to $0.3 \mathrm{~mm}$ and surface treatment of the spot by $15 \% \mathrm{HCl}$. The spot is markedly opaque. In traditional dentistry, it would be impossible to hide the opacity at this stage using composite in such a thin layer.

Fig. 11 : Après avoir éliminé 2 à $3 / 10^{\mathrm{e}}$ de $\mathrm{mm}$, et traité la surface de cette tache à l'HCl à $15 \%$. La tache est bien opaque. À ce stade en dentisterie traditionnelle, il sera impossible de cacher cette opacité par un composite sur une si petite épaisseur.

The main difficulty with this technique is judging at what moment it is possible to perform the infiltration.

\section{Alcohol, an indicator of the position of the ceiling of the lesion}

An indicator is required to show, in the case of MIH, whether the ceiling of the lesion has been reached and, in the other situations, whether the infiltration is sufficiently deep.

Alcohol can play this role. Since it has a relatively high refractive index it offers a preview, in a less effective way, of what will be achieved by the resin. When the application of
La difficulté principale de cette technique est de savoir à quel moment il est possible de procéder à l'infiltration.

\section{L'alcool, un indicateur de la position du plafond de la lésion}

II nous faut un indicateur pour savoir, dans le cas des $\mathrm{MIH}$, si le plafond de la lésion a été atteint, et dans les autres situations, si l'infiltration sera suffisamment profonde.

L'alcool va jouer ce rôle. Ayant un indice de réfraction assez élevé, il permet une prévisualisation, en moins efficace, de ce qui se passera avec la résine. Dès que l'application d'alcool 


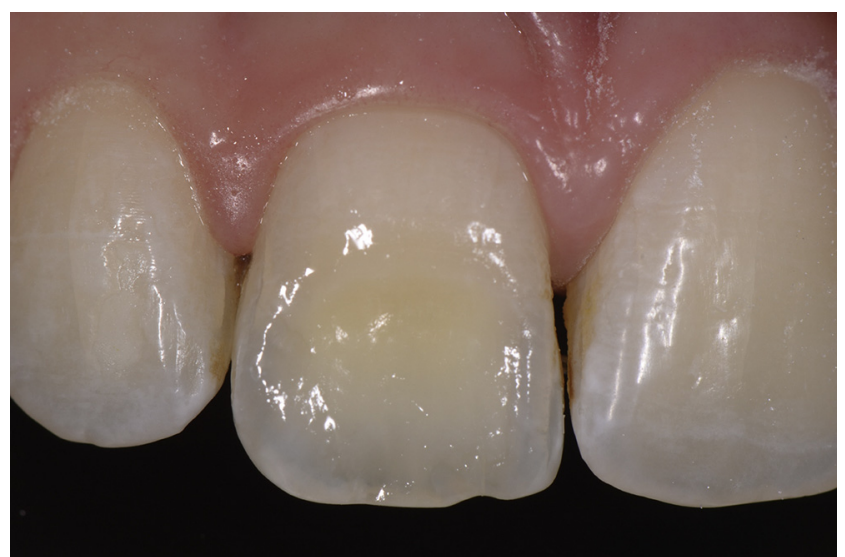

Fig. 12: Deep infiltration enables us to make the lesion translucent without further mutilation.

Fig. 12 : L'infiltration en profondeur nous permet, en restant au même niveau de mutilation, de rendre la lésion translucide.

alcohol seems to mask the lesion to some degree, this is a sign that the ceiling of the lesion has been reached or, in the case of a deep lesion, that the infiltration will be sufficient. If alcohol does not produce this effect, either chemical erosion should be repeated $(\mathrm{HCl})$ or further sandblasting or milling should be performed, specifically in the zones where no optical modification is visible (figs. 13-17). semble masquer légèrement la tâche, c'est le signe que nous avons atteint le plafond de la lésion, ou que l'infiltration sera suffisante en cas de lésion profonde. Si l'alcool ne procure pas cet effet, il faudra soit recommencer une étape d'érosion chimique $(\mathrm{HCl})$, soit sabler ou fraiser davantage, spécifiquement sur les zones qui n'ont pas subi la modification optique (fig. 13-17).

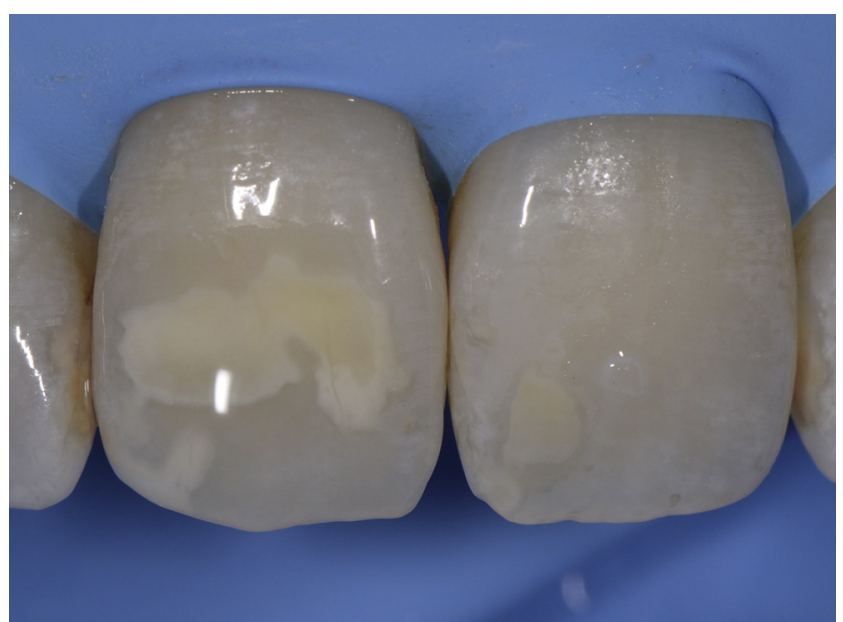

Fig. 13: Stage in the treatment of a deep lesion after milling, erosion and application of alcohol. An optical effect is visible at the center of the lesion but not peripherally. Moreover, the lesion close to the free edge of 11 has not been modified by alcohol. Further milling will be performed in these zones.

Fig. 13 : Étape d'un traitement d'une lésion profondeur après fraisage, érosion et application de l'alcool. Un effet optique est visible au centre de la lésion mais pas en périphérie. Par ailleurs, la lésion proche du bord libre de 11 n'est pas modifiée par l'alcool. Un fraisage supplémentaire est décidé sur ces zones. 


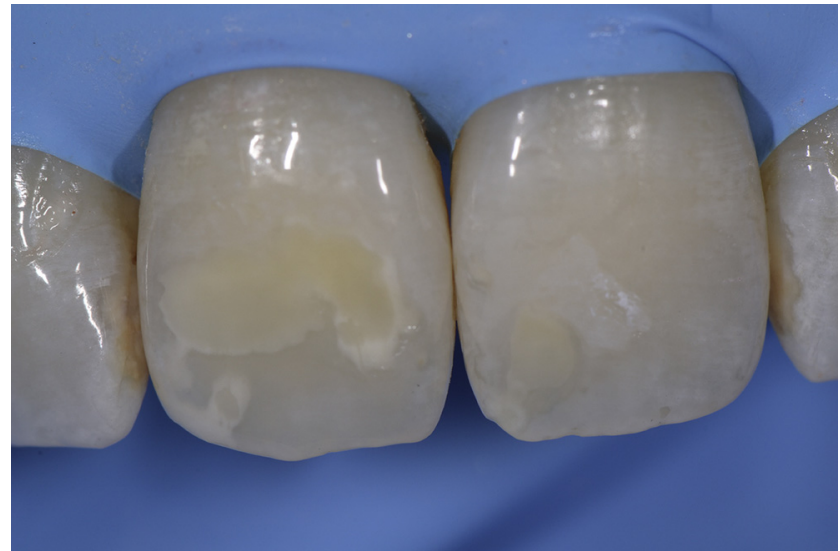

Fig. 14: After a new cycle of milling, erosion and alcohol, the optical appearance is improved but there are still zones, essentially peripheral, that remain unchanged. Another cycle will be performed.

Fig. 14 : Après un nouveau cycle fraisage, érosion et alcool, l'aspect optique est meilleur mais il persiste des zones, surtout en périphérie, qui restent inchangées. Un autre cycle est décidé.

Infiltration should never, in any circumstances, be performed if alcohol does not produce this optical modification!

\section{Efficacy of this approach for all types of etiology}

This deep infiltration technique has been proposed for the treatment of deep spots originating at the surface (fluorosis,
Dans tous les cas, il ne faudra jamais procéder à l'infiltration si l'alcool ne permet pas cette modification optique!

\section{Efficacité de la démarche quelle que soit l'étiologie}

Cette proposition d'infiltration en profondeur a été faite pour le traitement des taches profondes démarrant en superficie

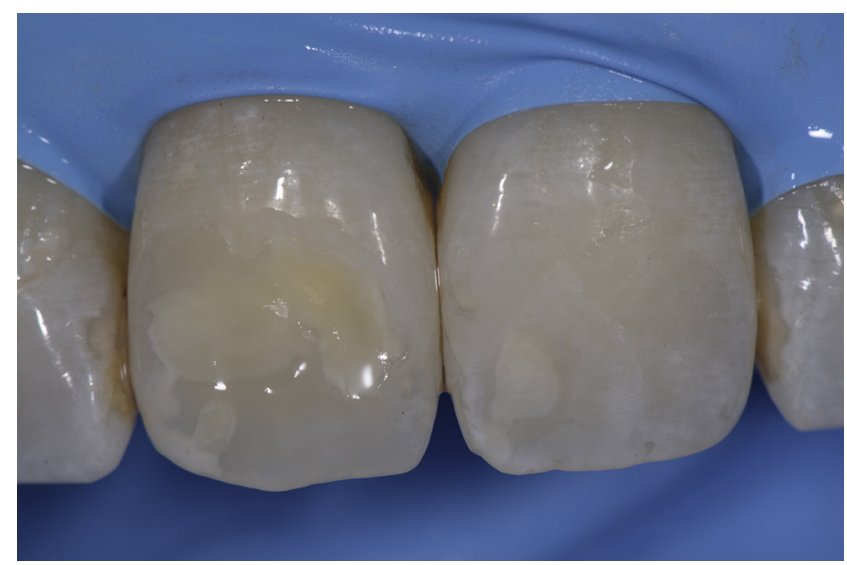

Fig. 15: After another cycle of milling, erosion and alcohol, the optical appearance is further improved but there remains a distal zone on 11 where the appearance has not changed. Another cycle of preparation is necessary.

Fig. 15 : Après un autre cycle fraisage, érosion et alcool, l'aspect optique est encore meilleur mais il persiste une zone en distal de 11 dont l'aspect optique n'est pas modifié. Un autre cycle est décidé. 


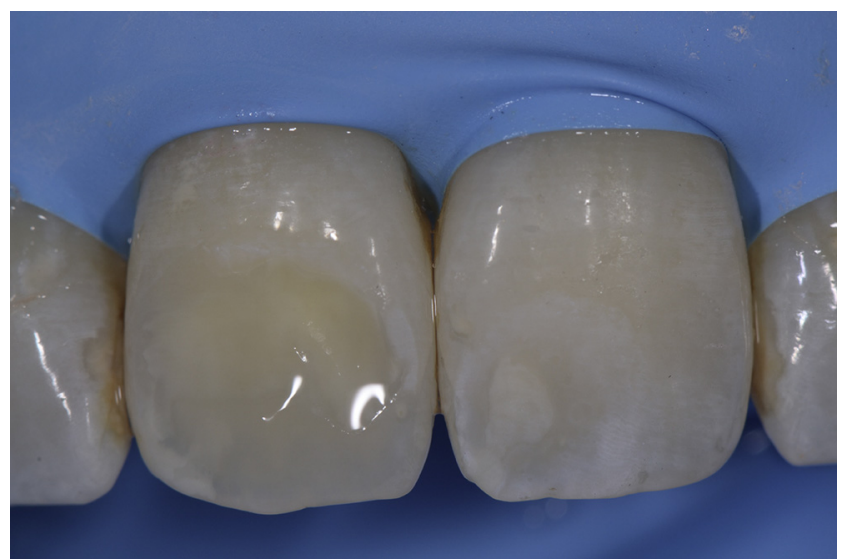

Fig. 16: After a further cycle of milling, erosion and alcohol, the optical change now concerns all lesions in totality and infiltration is possible.

Fig. 16 : Après un autre cycle fraisage, érosion et alcool, la modification optique concerne l'ensemble des lésions, l'infiltration est possible.

traumatic hypomineralization) or for those, like MIH, that originate at the dentino-enamel junction and for which, until now, no mini-invasive treatment was available. The method described can be applied to all spots, whatever their etiology. In fact, treatment of all white spots can be begun without sandblasting or milling; then, if this is not sufficient, additional chemical and mechanical treatments can be undertaken until alcohol produces an optical change. (fluorose, hypominéralisation traumatique) ou celles qui démarrent à la jonction émail/dentine, comme les MIH qui, jusqu'à présent, ne permettaient pas de traitement peu invasif. La méthodologie utilisée peut s'étendre à toutes les étiologies de taches. En effet, quelle que soit l'origine de la tâche, on peut commencer par un traitement sans sablage ni fraisage, puis si c'est insuffisant, on peut associer des traitements chimiques et mécaniques jusqu'au moment où l'alcool permet une modification optique.

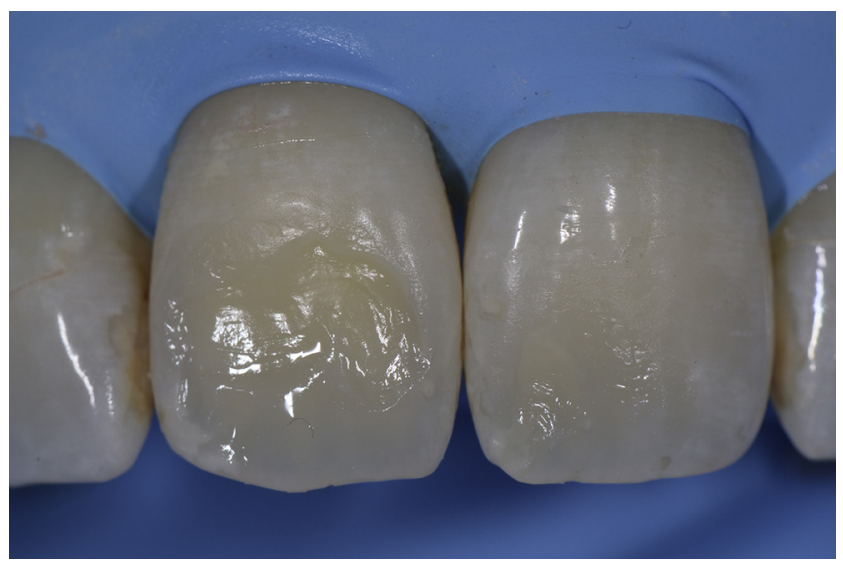

Fig. 17: Result of the infiltration. All the lesions are translucent. It only remains to fill the hollow by bonding a very small volume of composite.

Fig. 17 : Résultat de l'infiltration. L'ensemble des lésions est translucide. II ne reste plus qu'à combler la concavité par l'apport d'un très faible volume de composite. 


\section{Tissue preservation}

Compared with superficial infiltration, deep infiltration produces a slightly higher degree of mutilation, but always remains within the enamel. Since the natural optical characteristics of the tooth are restored the success of treatment depends simply on the quality of polishing of the fine onlay of composite.

\section{The place of whitening}

In the case of white spots

White spots are all the more visible, by contrast, when the rest of the healthy tooth is not particularly luminous. Whitening makes it possible to attenuate this contrast and thereby limit the visibility of white spots. Sometimes, at this stage, the patient is satisfied and does not wish to undertake further treatment.

In the case of colored spots

Lesions due to hypomineralization, whether superficial or deep, may be discolored. However, resin infiltration is not effective against pigmented spots. When the lesion is infiltrated, the color re-emerges very clearly. In the case of superficial infiltration, failure is immediate. In the case of deep infiltration, it is difficult to hide this coloring using composite. The ideal solution would be to restore a situation that we know how to treat (white spots). Therefore, whitening is often a useful technique so as to transform a pigmented spot into a white spot. As before, whitening alone may be enough and the patient may not wish to proceed to the infiltration stage (figs. 18 and 19). After whitening, it is necessary to wait two weeks before undertaking infiltration in order to avoid inhibition of resin curing [23]. If it is not possible to wait, some recent proposals may offer useful solutions [24].

\section{Cases where whitening is not possible (children under 18, financial problems, etc.)}

After rinsing with Icon Etch, apply 5\% sodium hypochlorite (with renewal of the solution) for 5 minutes. Sodium hypochlorite eliminates some of the proteins responsible for discoloring. The operation often has to be renewed after further applications of Icon Etch. This solution is much less effective than whitening and is often quite tedious.

\section{Préservation tissulaire}

Par rapport à l'infiltration superficielle, l'infiltration en profondeur est légèrement plus mutilante, mais dans tous les cas nous restons dans l'émail. Le support retrouvant les propriétés optiques naturelles de la dent, la réussite du traitement est liée à la simple qualité du polissage de la couche fine d'apposition de composite.

\section{Place de l'éclaircissement}

\section{Dans le cas des taches blanches}

Par effet de contraste, les taches blanches sont d'autant plus visibles que le reste de la dent saine est peu lumineuse. Ainsi l'éclaircissement va permettre d'atténuer le contraste et donc de limiter la visibilité des taches blanches. Parfois à ce stade le patient est satisfait et ne souhaite plus aller plus loin dans le traitement.

\section{Dans le cas des taches colorées}

Qu'elles soient superficielles ou profondes, les lésions d'hypominéralisation peuvent être colorées. Or l'infiltration de résine ne fonctionne pas sur les tâches colorées. En effet, lors de l'infiltration de la lésion, une résurgence colorée apparaît nettement. Dans le cas d'infiltration superficielle, l'échec est immédiat. Dans le cas d'infiltration en profondeur, il sera difficile de cacher cette coloration par un composite. L'idéal serait de se remettre dans une situation que nous savons traiter (tache blanche). C'est pourquoi l'éclaircissement est souvent utile afin de transformer la tache colorée en tache blanche. Comme précédemment il peut arriver que l'éclaircissement soit suffisant et que le patient ne souhaite pas procéder à l'étape d'infiltration (fig. 18 et 19). Après la fin de l'éclaircissement nous attendrons 15 jours avant de passer à la phase d'infiltration afin d'éviter l'inhibition de la polymérisation des résines [23]. S'il n'est pas possible d'attendre, nous pouvons nous inspirer de propositions récentes [24].

\section{Cas où l'éclaircissement n'est pas possible (enfant de moins de 18 ans, coûts financiers. . .)}

Après le rinçage de l'Icon Etch, appliquer (en renouvelant la solution) de l'hypochlorite de sodium à $5 \%$ pendant 5 minutes. L'hypochlorite de sodium permet d'éliminer une partie des protéines responsables des colorations. Cette application doit souvent être renouvelée après d'autres applications d'Icon Etch. Cette solution, beaucoup moins efficace que l'éclaircissement, est toutefois assez fastidieuse. 


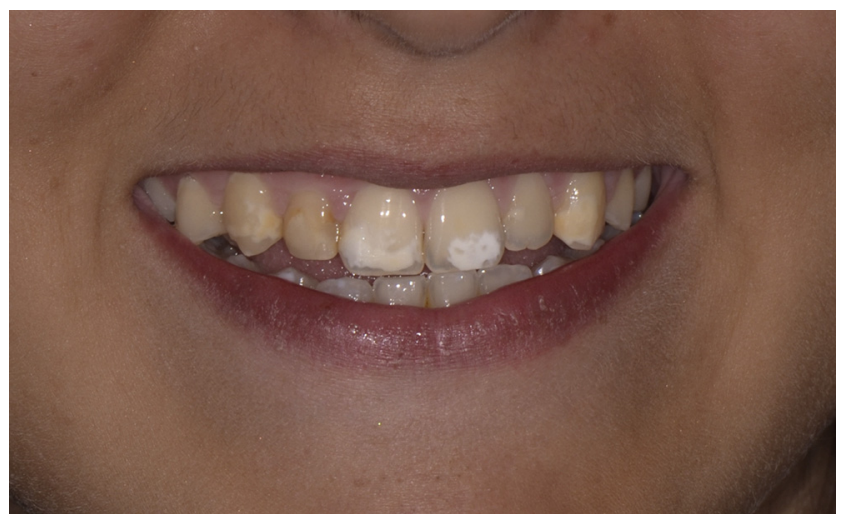

Fig. 18: This young patient suffering from severe fluorosis was looking for an esthetic solution to the serious defects in her smile. A phase of whitening was proposed, with the idea of performing infiltration in a second phase.

Fig. 18 : Cette jeune patiente atteinte de fluorose sévère souhaite une solution esthétique à la disgrâce importante de son sourire. Une phase d'éclaircissement lui est proposée, en anticipant une $2^{\mathrm{e}}$ phase d'infiltration.

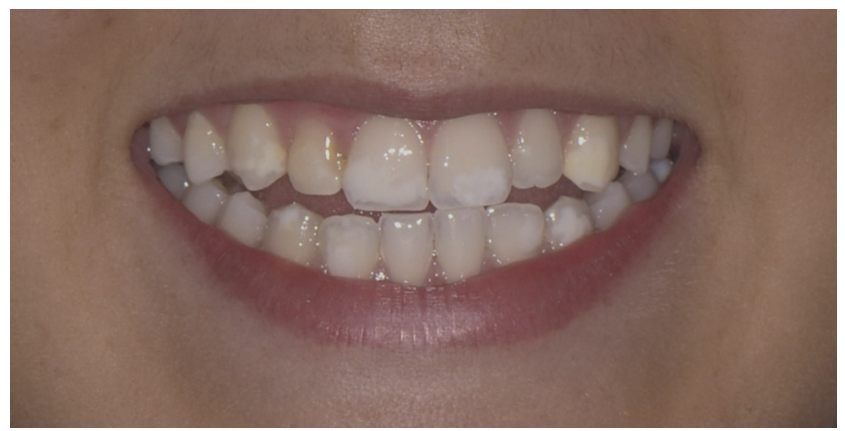

Fig. 19: Whitening has clearly improved the appearance of her smile, with lessening of the contrast. The patient is perfectly satisfied and does not wish to undertake further treatment.

Fig. 19 : L'éclaircissement a nettement amélioré l'aspect esthétique du sourire. Le contraste a diminué. La patiente est très satisfaite et ne souhaite pas aller plus loin.

\section{Aging of the resin used for infiltration}

Many authors have raised the question of the aging of the resin used for infiltration and remain very prudent in their conclusions $[18,25]$. Recent in vitro studies give contradictory results. Some authors consider that infiltrated enamel remains stable for at least 6 months [26] or that infiltrated, wellpolished enamel is resistant to discoloration (13). Others see this problem as one of the drawbacks of the technique [27]. It should be noted that the problem only really arises in the case of superficial infiltration, since in the situation of deep infiltration the resin is not in contact with the external environment, or is in contact only through the adhesive bond.

\section{Vieillissement de la résine d'infiltration}

De nombreux auteurs se sont interrogés sur le vieillissement de la résine d'infiltration, ce qui les a conduit à rester très prudents $[18,25]$. Les études récentes in vitro semblent contradictoires. Certains trouvent que l'émail infiltré présente une stabilité au moins sur 6 mois [26] ou que l'émail infiltré et bien poli est résistant à la coloration (13). D'autres pensent qu'il s'agit d'un des inconvénients de la technique [27]. Notons que ce problème ne se pose vraiment que dans le cas d'infiltration superficielle, car dans les cas d'infiltration en profondeur la résine n'est pas au contact du milieu extérieur ou simplement par son joint adhésif. 
Our experience is somewhat different: in the case of superficial infiltration we have noted, like other authors [16], an improvement of the result over time. This improvement could be explained by absorption by the resin of water that was not eliminated by the ethyl alcohol. This absorption could lead to a reduction in optical interfaces in the light path and thereby to an improvement in the translucence of the lesion.

The two clinical cases below sum up the findings of this article. The first case was treated by Dr. Attal ((figs. 2029)). The second case was treated by Dr. Maud Denis (figs. 30-54).
Notre expérience est un peu différente car dans les cas d'infiltration superficielle, nous observons, comme d'autres auteurs [16] une amélioration dans le temps du résultat obtenu. Cette amélioration pourrait s'expliquer par l'absorption par la résine d'eau qui n'a pas été chassée par l'éthanol. Cette absorption entraînerait une diminution des interfaces optiques pour la lumière et donc une amélioration de la translucidité de la lésion. Les 2 cas cliniques suivants synthétisent l'ensemble des données de cet article. Le $1^{\mathrm{er}}$ cas clinique a été traité par le Dr Attal ((fig. 20-29)). Le $2^{\mathrm{e}}$ cas clinique a été traité par le Dr Maud Denis (fig. 30-54).

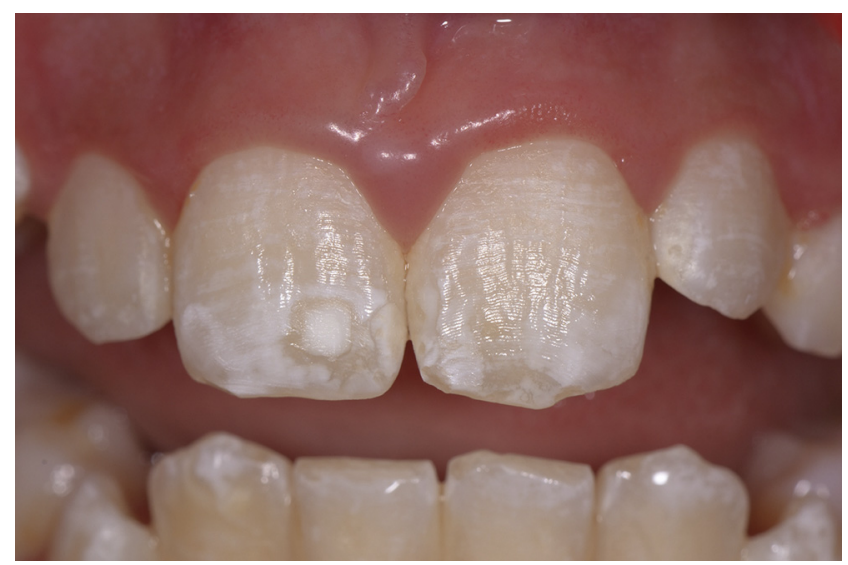

Fig. 20: Layered white spot lesions linked to fluorosis, combined with an extremely opaque white spot due to MIH (on 11, square shape). Superficial infiltration is planned in the superficial lesions (fluorosis) and deep infiltration into the deep lesion (MIH).

Fig. 20 : Taches blanches en nappes liées à une fluorose, associées à une tache blanche très opaque liée à une $\mathrm{MIH}$ (sur la 11, forme carrée). Nous anticipons réaliser une infiltration superficielle sur les lésions superficielles (fluorose) et une infiltration profonde sur la lésion profonde $(\mathrm{MIH})$.

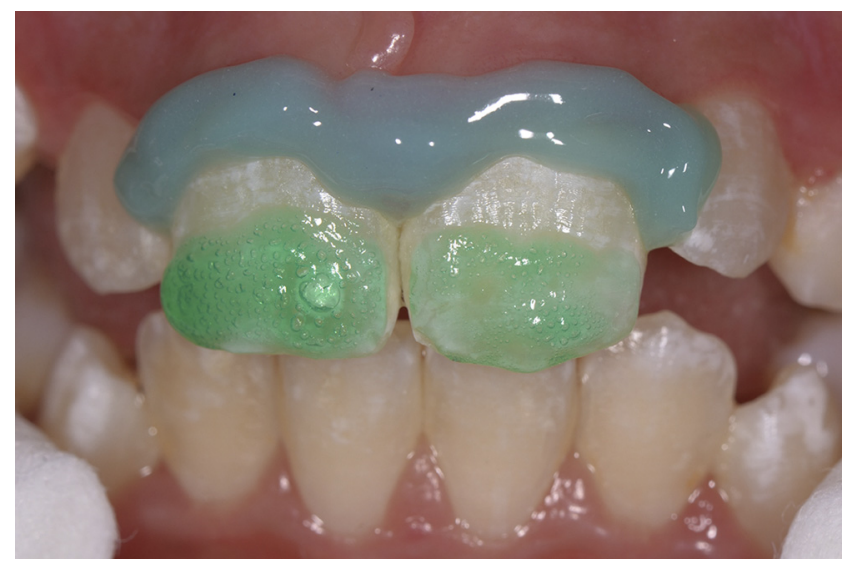

Fig. 21: Positioning of a light-curable liquid dam, then first phase of erosion with $\mathrm{HCl}$.

Fig. 21 : Mise en place d'une digue liquide photopolymérisable, puis première érosion à l'HCl. 


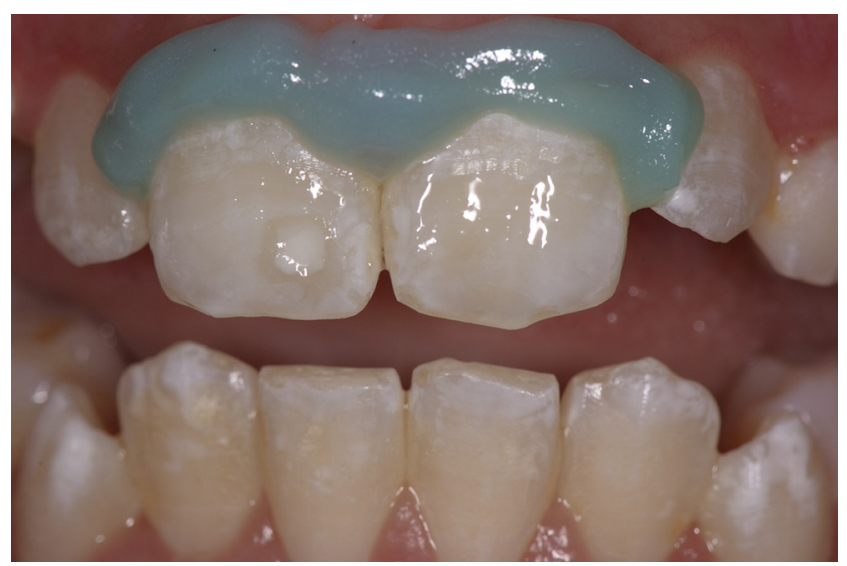

Fig. 22: Application of alcohol shows a slight optical change on the level of the fluorosis but the change is far from sufficient on the level of the deep spot. Deep infiltration will be performed here, prepared by milling.

Fig. 22 : L'application de l'alcool montre une légère modification optique au niveau de la fluorose mais la modification est très insuffisante au niveau de la tache profonde. Une infiltration en profondeur à ce niveau est décidée par fraisage.

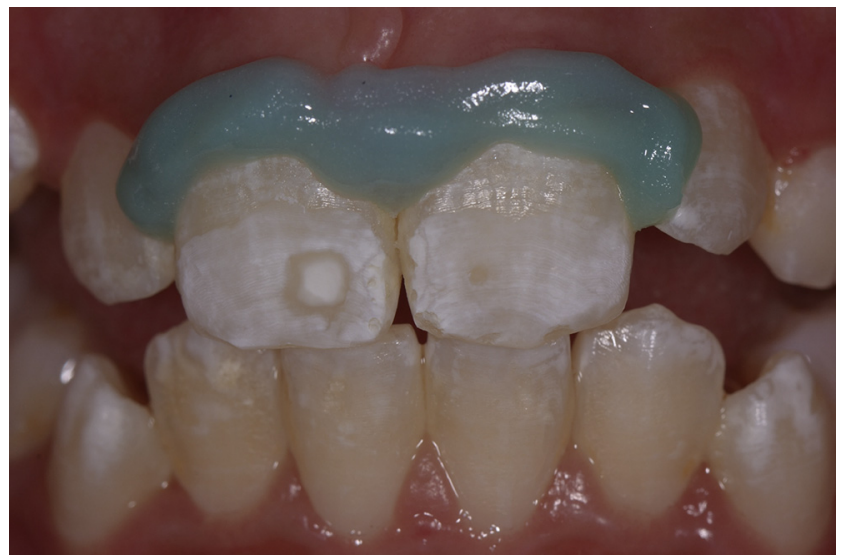

Fig. 23: View after milling of the opaque square, erosion, rinsing and drying.

Fig. 23 : Vue après fraisage du carré opaque, érosion, rinçage et séchage. 


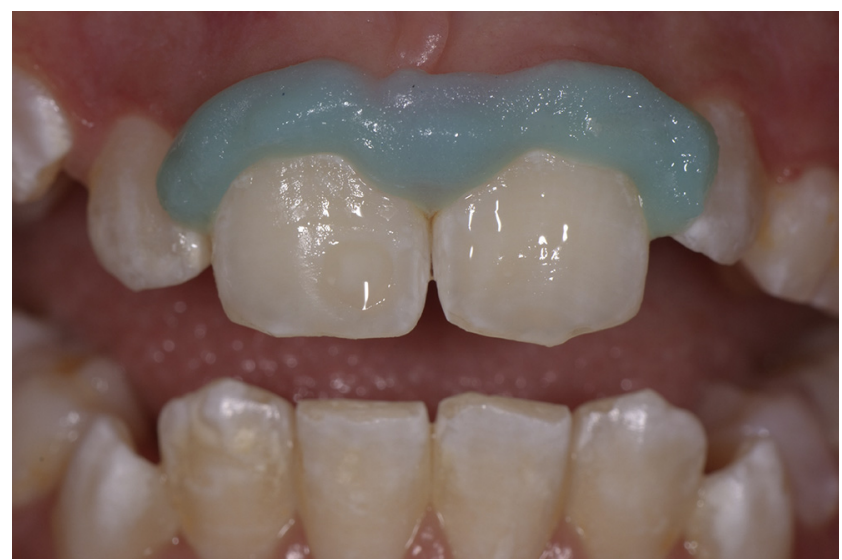

Fig. 24: 3 stages of (very light) milling and erosion were necessary to obtain this optical effect after application of alcohol. Infiltration is now possible.

Fig. 24 : Trois étapes de fraisage (très léger) et d'érosion sont nécessaires pour obtenir cet effet optique après application de l'alcool. L'infiltration est maintenant possible.

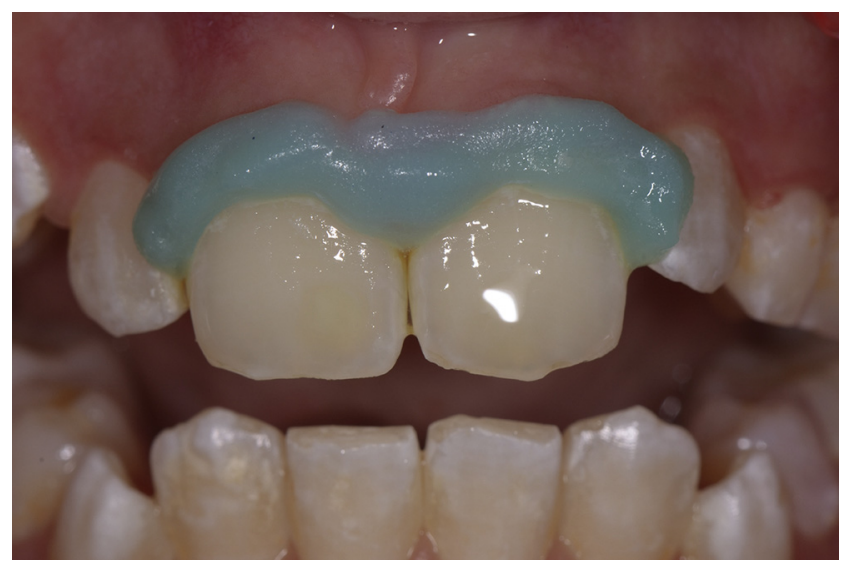

Fig. 25: Infiltration of Icon Infiltrant. Note that this resin appears slightly yellow since it contains camphorquinone.

Fig. 25 : Infiltration à l'aide d'Icon Infiltrant. Notons que cette résine présente un aspect légèrement jaune car elle contient de la camphoroquinone. 


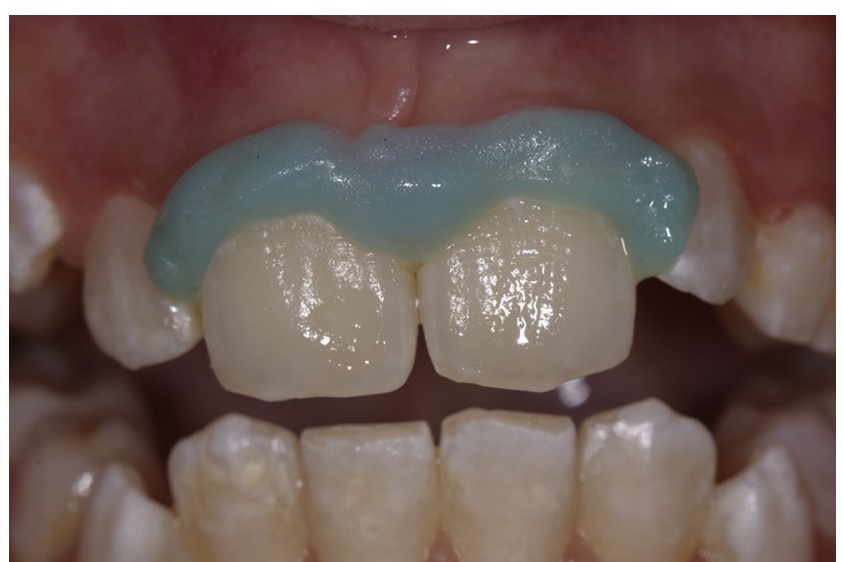

Fig. 26: View after light-curing. The yellow tinge has disappeared because the camphorquinone has been consumed. Next, composite will be placed on the square part of the tooth that was drilled.

Fig. 26 : Vue après photopolymérisation. L'aspect jaune a disparu car la camphoroquinone a été consommée. Puis mise en place du composite sur la portion cariée de la dent qui a été fraisée.

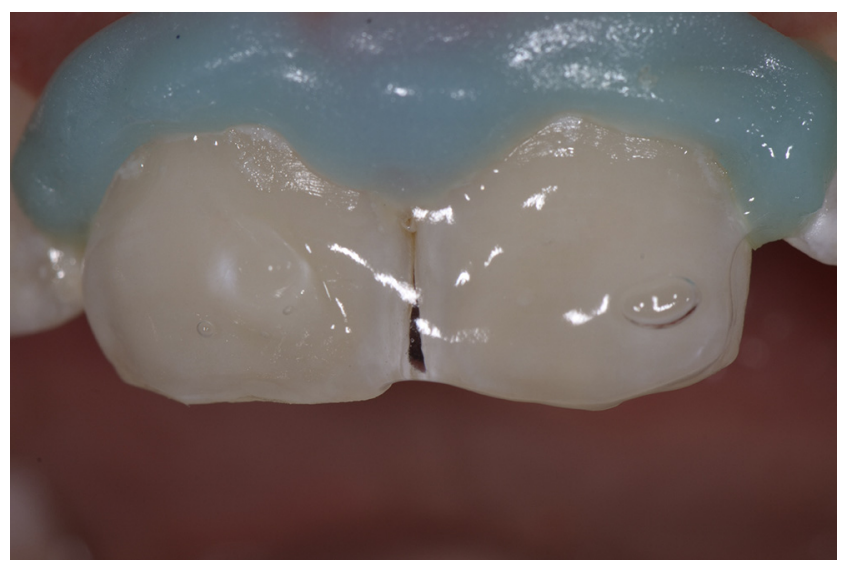

Fig. 27: Application of glycerin on all surfaces followed by lightcuring.

Fig. 27 : Mise en place de glycérine sur l'ensemble des surfaces, suivie d'une photopolymérisation. 


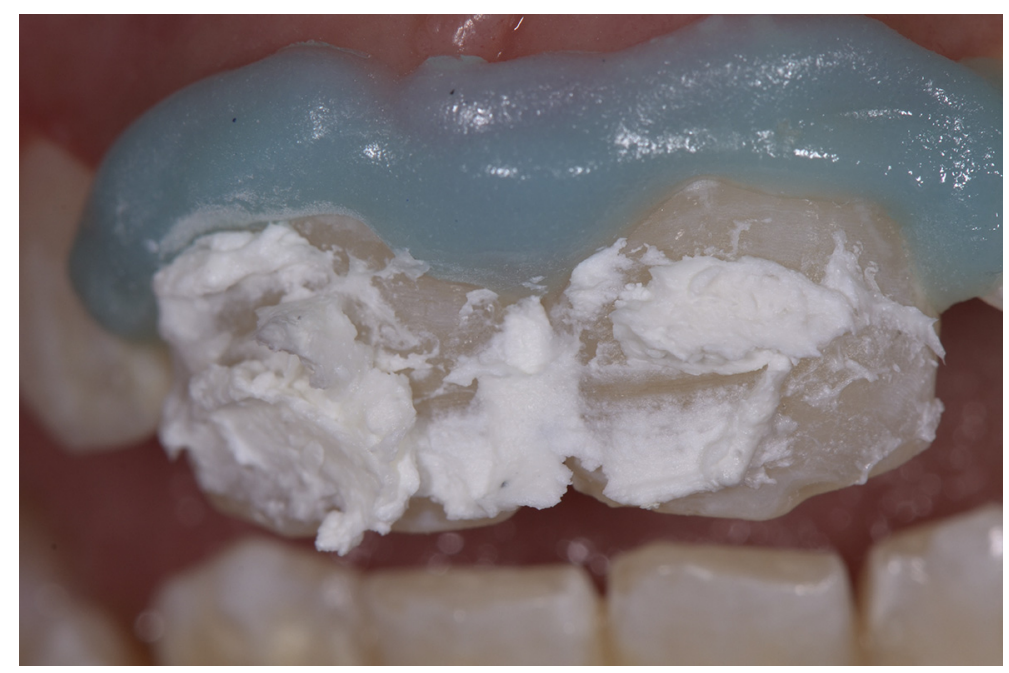

Fig. 28: Polishing, using diamond paste and mini-brushes.

Fig. 28 : Polissage à l'aide d'une pâte diamantée et de brossettes.

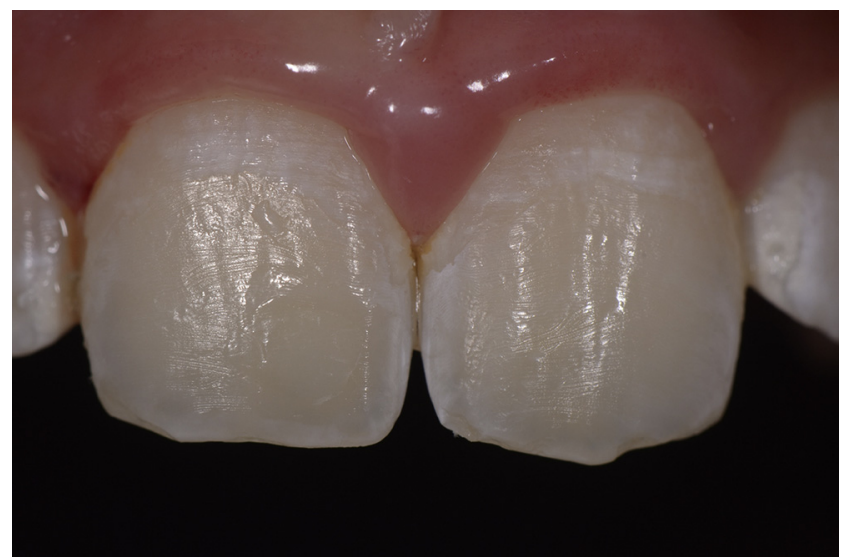

Fig. 29: Final result.

Fig. 29 : Résultat final. 


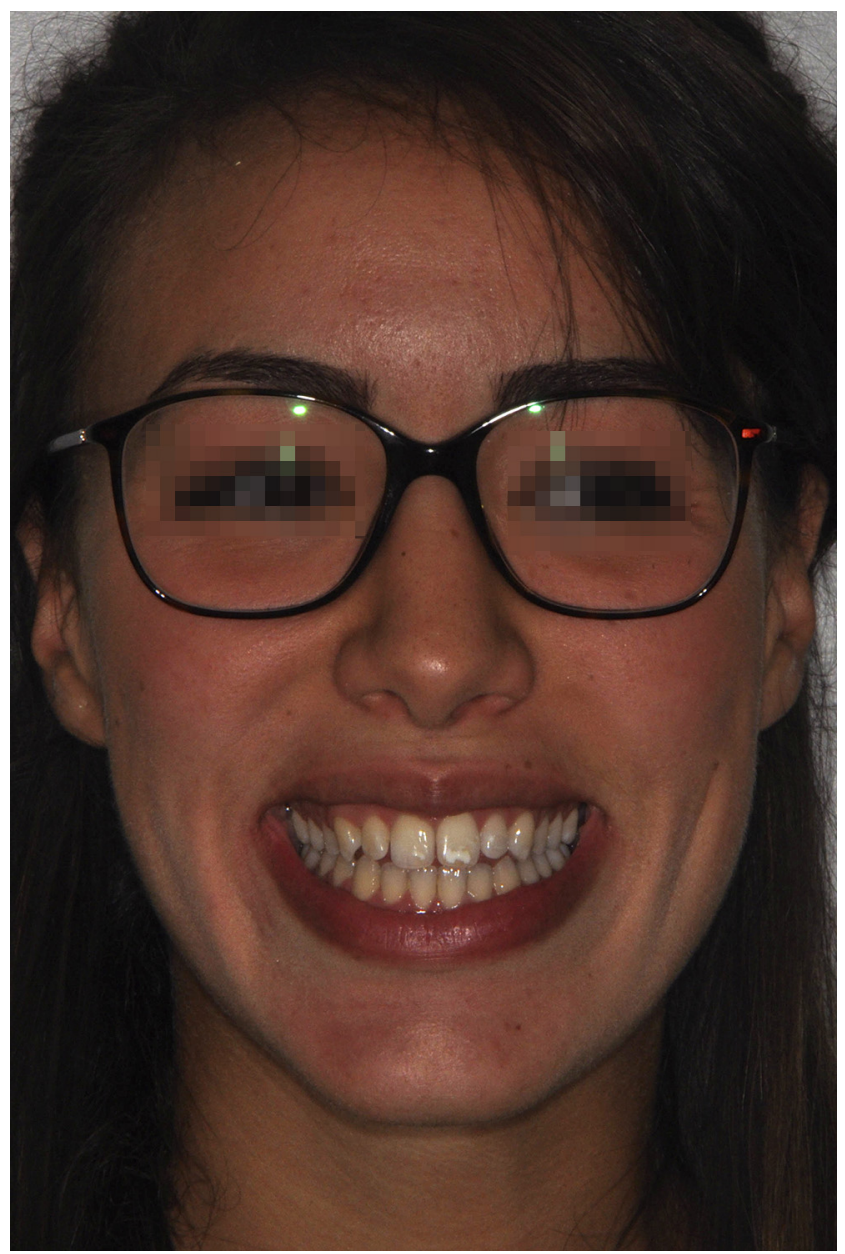

Fig. 30: When she smiles this patient reveals a large white spot located towards the incisal edge of 21 . She would like us to improve the appearance of this tooth, which alters her smile.

Fig. 30 : Lors du sourire la patiente révèle une tache blanche importante localisée dans la partie incisale de sa 21. Elle souhaite qu'on améliore l'aspect de sa dent qui altère son sourire. 

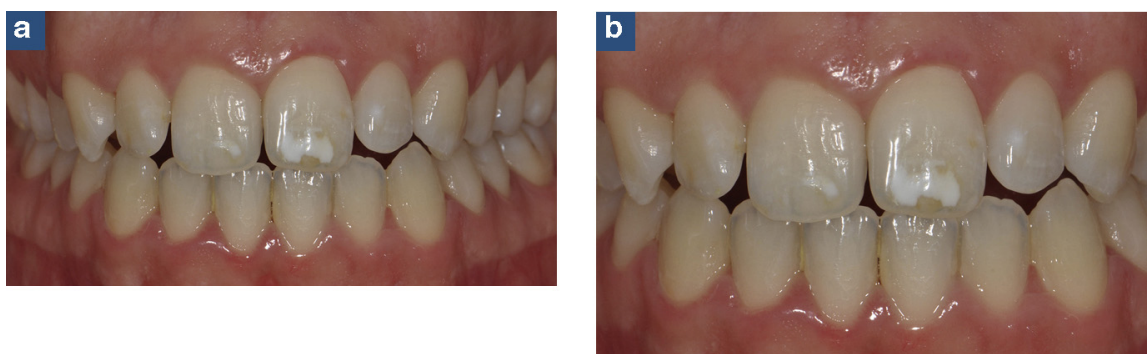

Fig. 31: a, b: at the oro-dental level, the enamel of all the upper incisors is affected, with the presence of white spots of different shapes and sizes localized in the incisal half of each tooth. Involvement is asymmetrical, predominantly on 21 . The discoloration of 21 is complicated by a brownish halo around the white spot. The lower incisors and the molars are not involved.

Fig. 31 : a, b : à l'échelle buccodentaire, l'atteinte amélaire concerne l'ensemble des incisives supérieures avec la présence de taches blanches de taille et de forme variables, localisées dans la moitié incisale. L'atteinte est asymétrique et prédomine sur la 21. La dyschromie de la 21 se complique d'un halo brunâtre autour de la lésion blanche. Les incisives mandibulaires, ainsi que les molaires sont indemnes.

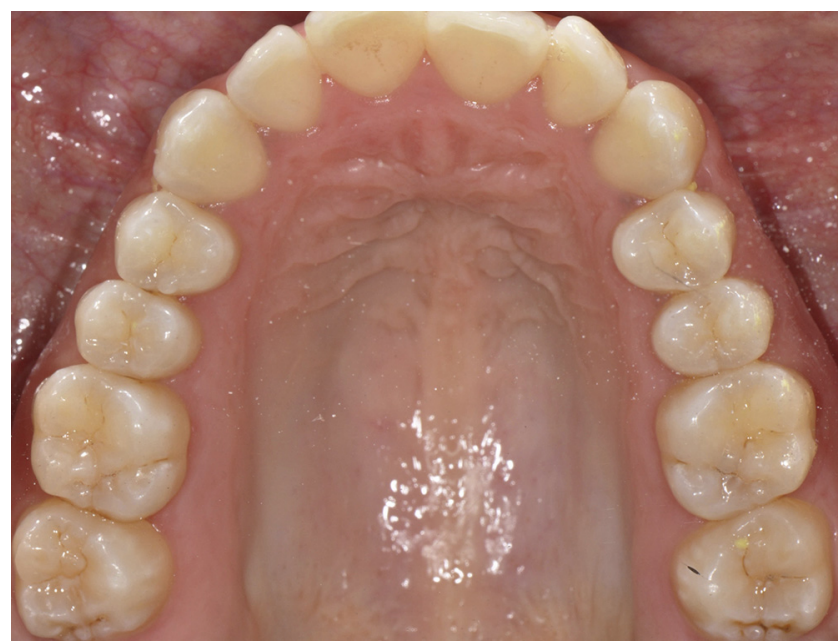

Fig. 32: Maxillary occlusal view, confirming the absence of lesions on the enamel of the first molars (this is also the case on the lower arch). The clinical situation leads to a diagnosis, by elimination, of "hypomineralization of traumatic origin".

Fig. 32 : La vue occlusale maxillaire permet de confirmer l'absence d'atteinte amélaire des premières molaires (c'est aussi le cas à la mandibule). Le tableau clinique permet de diagnostiquer, par élimination, une « hypominéralisation d'origine traumatique ». 

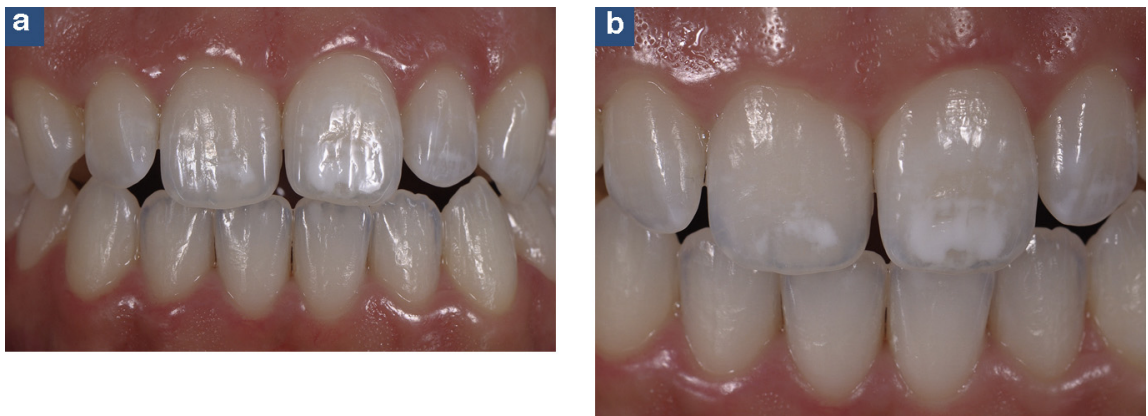

Fig. 33: a, b: clinical situation after three weeks of outpatient whitening. The increased brightness of the healthy enamel reduces the dominance of the spots, which nevertheless remain visible. The patient wishes to go further in the attempt to mask the spots.

Fig. 33 : $a, b$ : situation clinique après trois semaines d'éclaircissement ambulatoire. L'augmentation de luminosité de l'émail sain réduit la dominance des taches, mais ces dernières restent visibles. La patiente souhaite aller plus loin dans le masquage des taches.

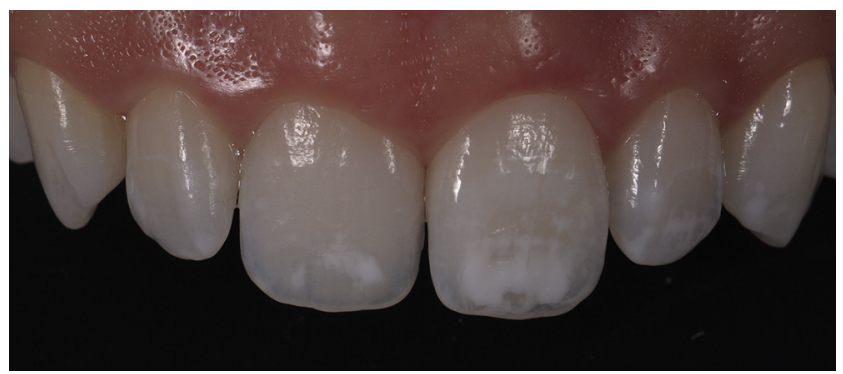

Fig. 34: The elimination of the chromophores after whitening is perfectly visible.

Fig. 34 : L'élimination de protéines chromophores après éclaircissement est parfaitement visualisée.

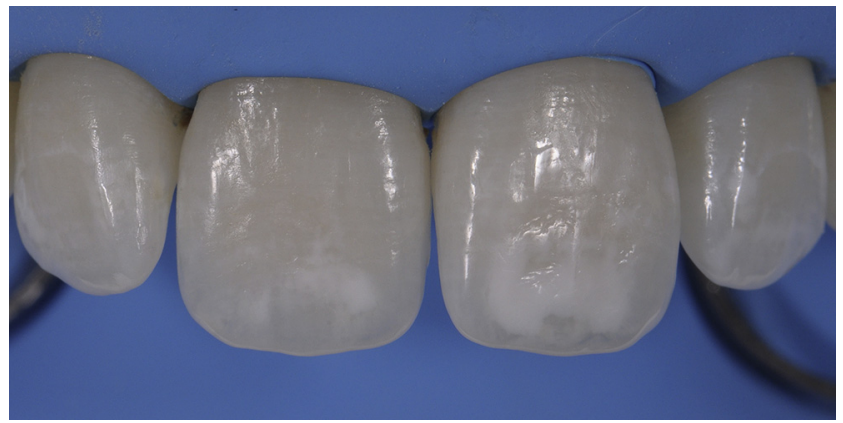

Fig. 35: Clinical situation after preparation of operating zone.

Fig. 35 : Situation clinique après pose du champ opératoire. 


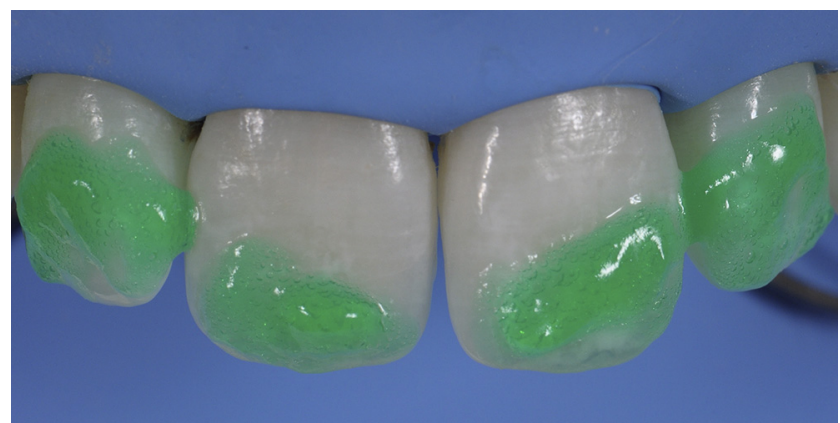

Fig. 36: Application of hydrochloric acid on the enamel lesions for 2 minutes.

Fig. 36 : Application de l'acide chlorhydrique sur les zones d'émail lésé pendant 2 minutes.

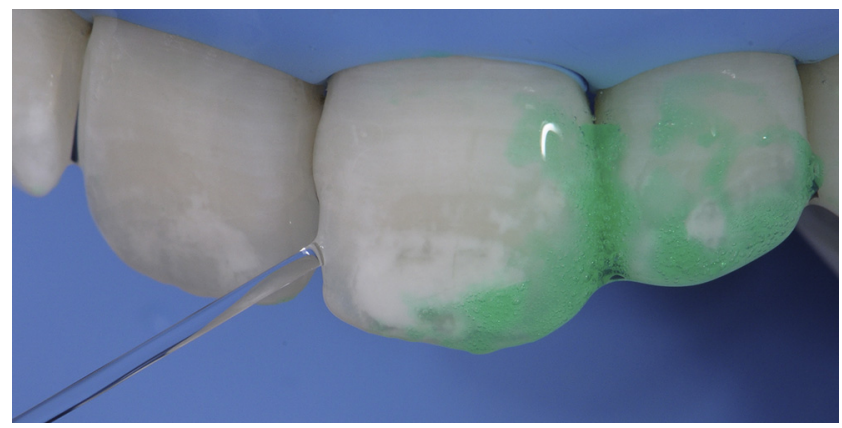

Fig. 37: Thorough rinsing for 30 seconds.

Fig. 37 : Rinçage abondant pendant 30 secondes.

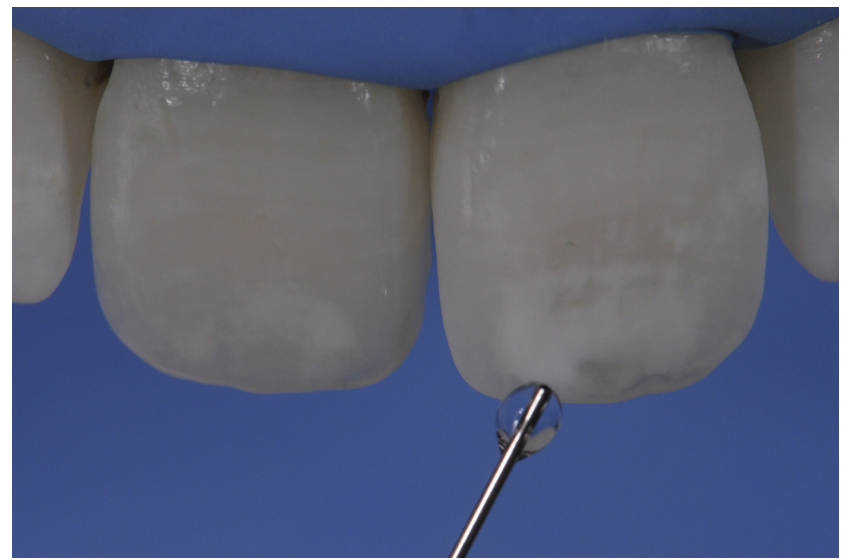

Fig. 38: Appearance of the lesions on 11 and 21 after erosion and just before application of the alcohol solution.

Fig. 38 : Aspect des lésions de 11 et 21 après érosion et juste avant application de la solution alcoolique. 


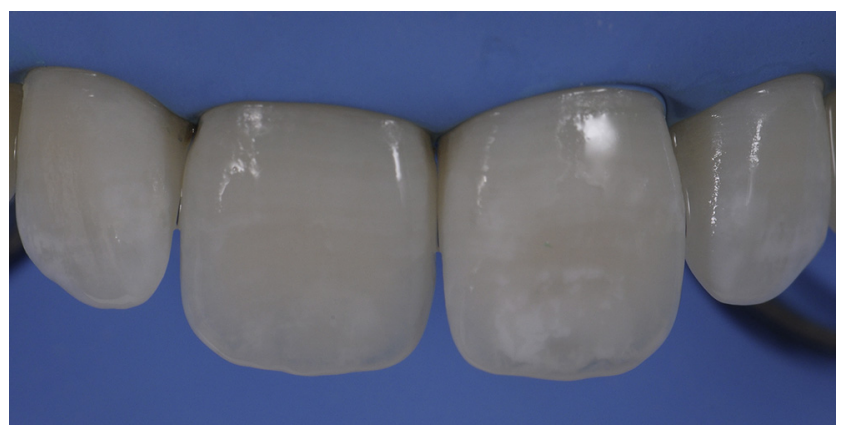

Fig. 39: Optical appearance of the teeth after application of the alcohol solution. Impregnation by alcohol, with its high refractive index, simulates the final result. Opacity persists, predominantly on 21. Deep infiltration is decided on, and a sandblasting stage will be performed on this tooth.

Fig. 39 : Aspect optique des dents après application de la solution alcoolique. L'imprégnation de l'alcool d'indice de réfraction élevé vient simuler le résultat final. Les opacités persistent avec une large prédominance sur la 21. Une infiltration en profondeur est décidée et une étape de sablage est réalisée sur cette dent.

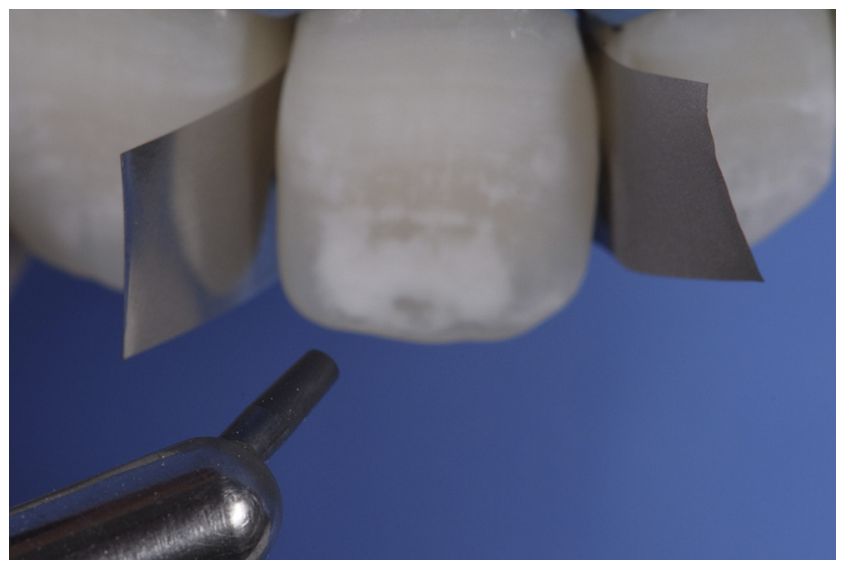

Fig. 40: A metallic matrix is placed so as to isolate 21 and protect the enamel surfaces of adjacent teeth. Selective sandblasting is then performed.

Fig. 40 : Une matrice métallique est positionnée afin d'isoler la 21 et de protéger les surfaces amélaires des dents adjacentes. Le sablage sélectif est ensuite réalisé. 


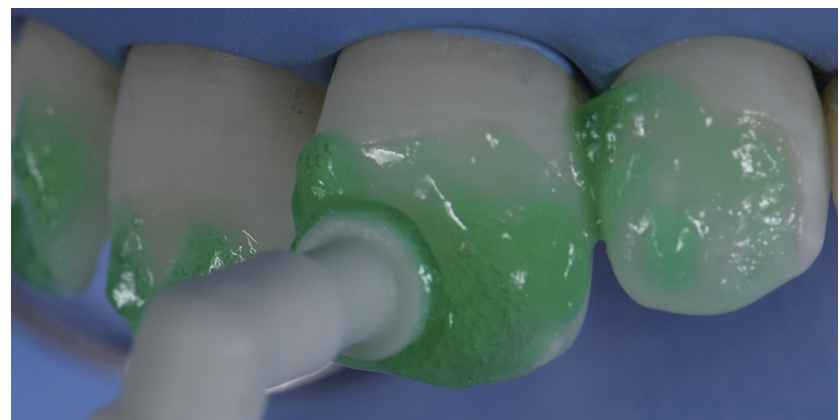

Fig. 41: Hydrochloric acid is again applied to all the persistent lesions.

Fig. 41 : Une nouvelle application d'acide chlorhydrique est réalisée sur l'ensemble des atteintes persistantes.

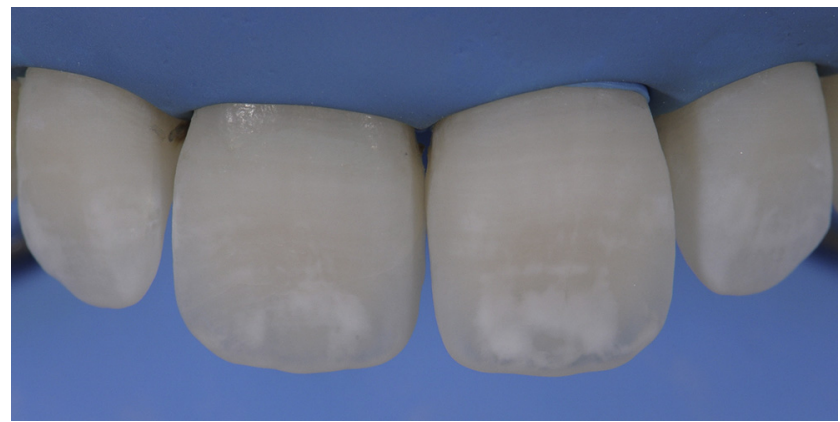

Fig. 42: Clinical appearance after careful rinsing and drying. Despite the surface erosion treatment and sandblasting (on 21), the heart of the lesions has been preserved.

Fig. 42 : Aspect clinique après rinçage et séchage minutieux. Malgré le traitement érosif de surface et le sablage (sur 21) le cœur des lésions est préservé.

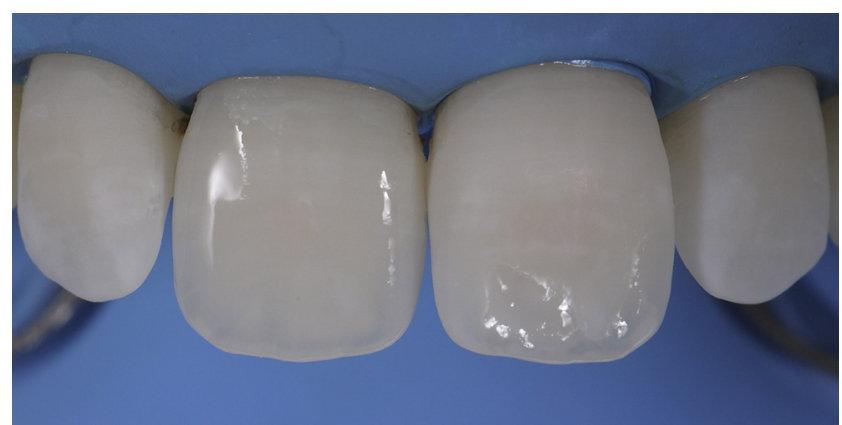

Fig. 43: Optical appearance of the lesions after application of the alcohol solution. The capacity for impregnation is judged to be optimal. Application of alcohol also ensures that the body of each lesion is thoroughly dehydrated; this is a necessary stage before resin infiltration.

Fig. 43 : Aspect optique des lésions suite à l'application de la solution alcoolique. La capacité d'imprégnation est évaluée optimale. La solution assure de plus la déshydratation complète du corps des lésions ; étape nécessaire avant infiltration résineuse. 
White spots on enamel: Treatment protocol by superficial or deep infiltration (part 2) Taches blanches de l'émail : protocole de traitement par infiltration superficielle ou en profondeur (partie 2)

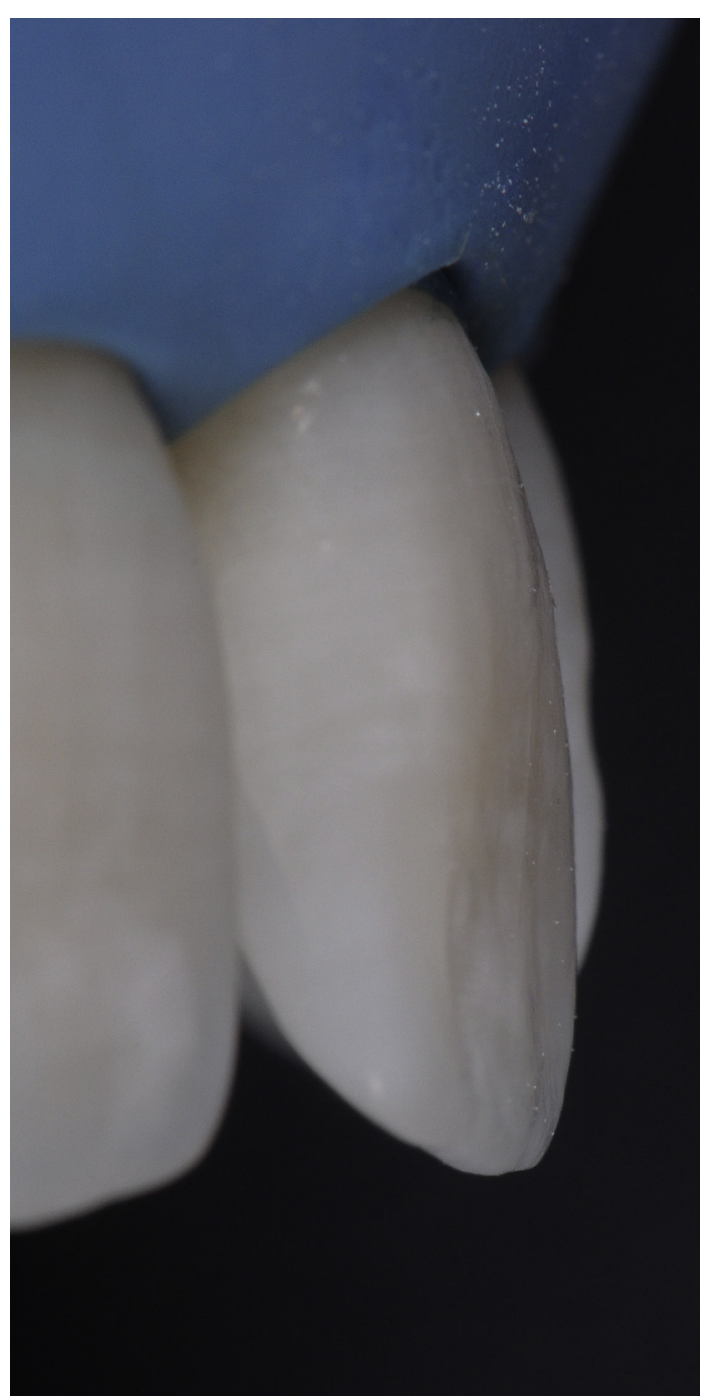

Fig. 44: The profile view shows the quantity of tissue eliminated by the procedure used to relocalize the ceiling. Elimination of enamel is minimal.

Fig. 44 : La vue de profil permet de visualiser la quantité de tissu éliminé par la procédure de relocalisation du plafond. L'élimination amélaire a été minime. 


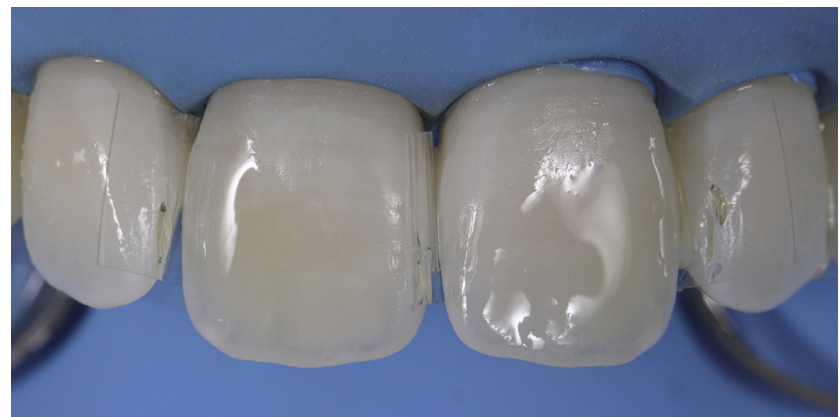

Fig. 45: Application of the resin directly on the opacities. A certain time (2 minutes) is necessary for infiltration.

Fig. 45 : Application de la résine d'infiltration directement sur les opacités. Un certain temps d'infiltration est nécessaire (2 minutes).

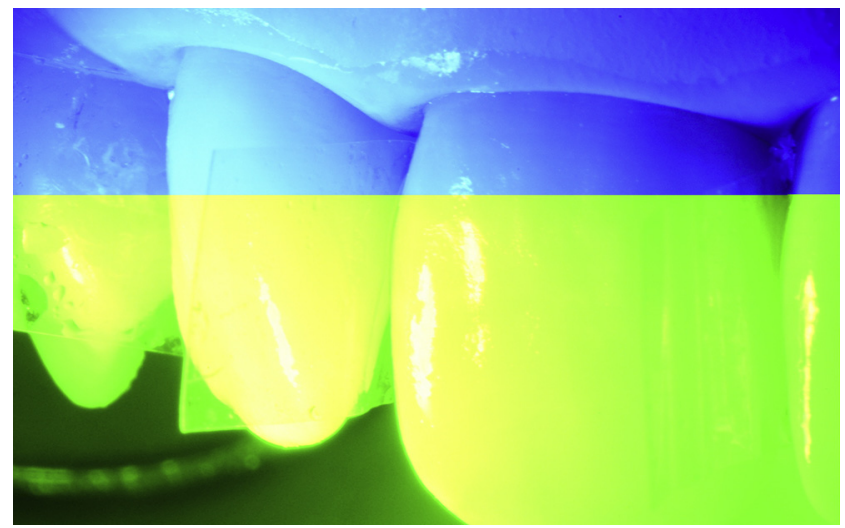

Fig. 46: After elimination of excess material by air spray, lightcuring is performed.

Fig. 46 : Après élimination des excès par spray d'air, la polymérisation est réalisée.

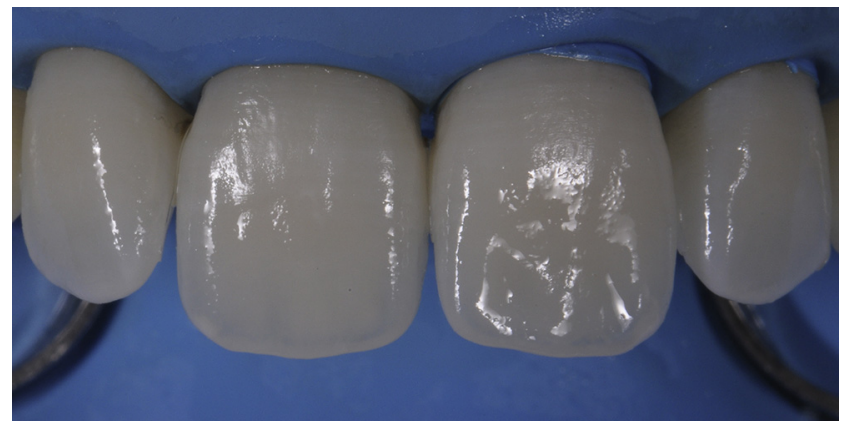

Fig. 47: Optical appearance of the lesions after infiltration. Fig. 47 : Aspect optique des lésions après infiltration. 


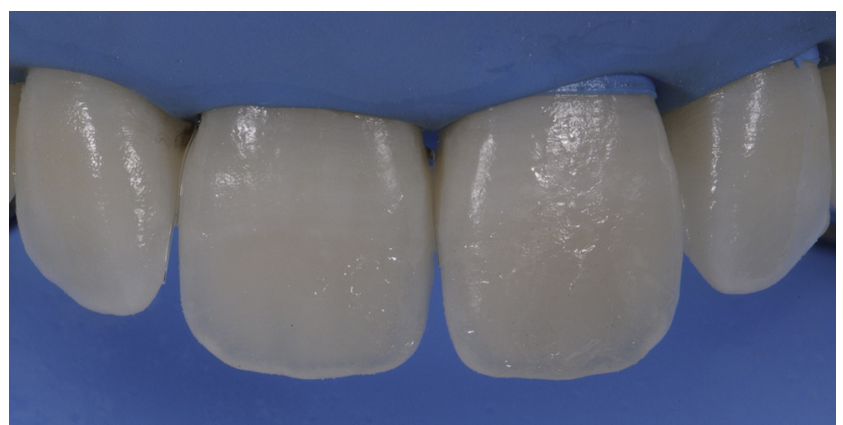

Fig. 48: The minimal loss of substance on 21 prompts the application of a thin composite build-up to this tooth. One single shade of enamel was used. The composite chosen was Enamel HRi by Micerium. Note that the refractive index of this composite, 1.53, seems to be favorable in this case. No stratification is required.

Fig. 48 : La perte de substance minime créée sur 21 a conduit à l'application d'un petit incrément de composite sur 21. Une seule teinte émail a été apportée. Le choix du composite s'est tourné vers l'Enamel HRi de chez Micerium. Notons que l'indice de réfraction de ce composite de 1,53 semble favorable dans ce cas. Aucune technique de stratification n'est nécessaire.

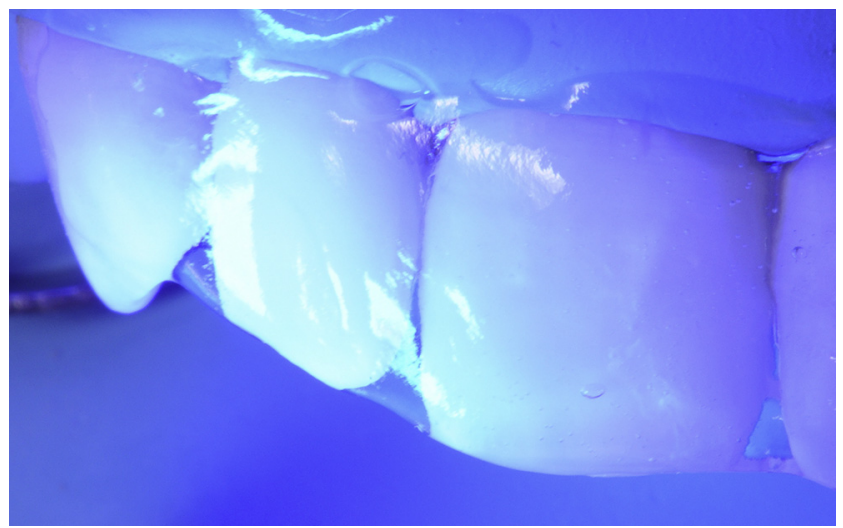

Fig. 49: Light curing under glycerin for optimal polymerization of the resin surface layer (Icon and composite).

Fig. 49 : Polymérisation sous glycérine assurant la polymérisation optimale de la couche résineuse de surface (Icon et composite). 


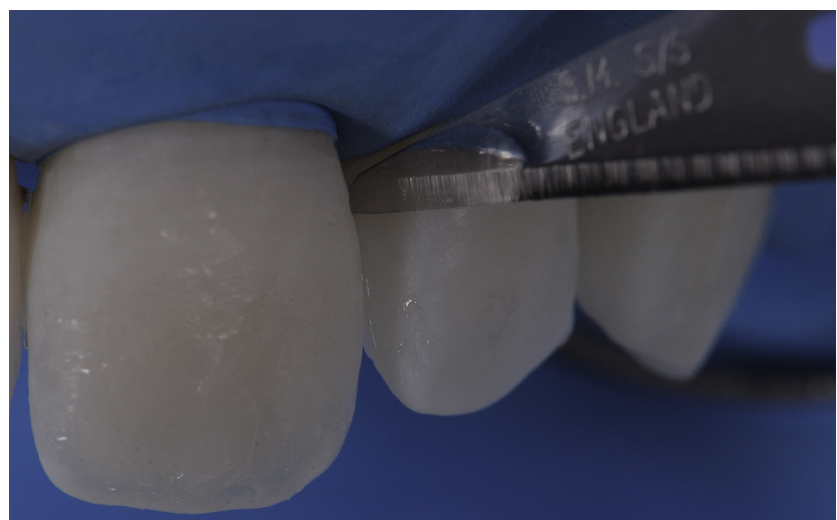

Fig. 50: Elimination of excess material and conventional polishing procedure.

Fig. 50 : Élimination des excès et procédure conventionnelle de polissage.
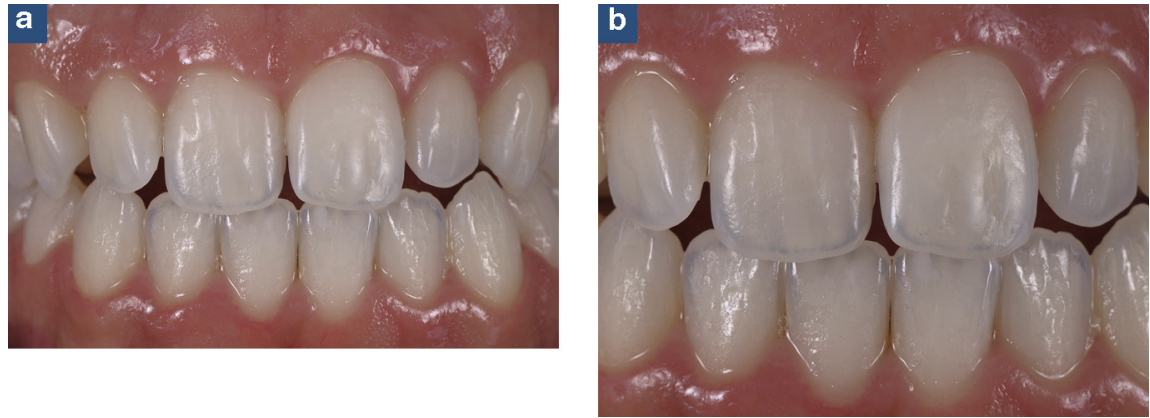

Fig. 51: a, b: oro-dental situation one week after end of treatment.

Fig. 51 : $a, b$ : situation buccodentaire 1 semaine après la fin du traitement.

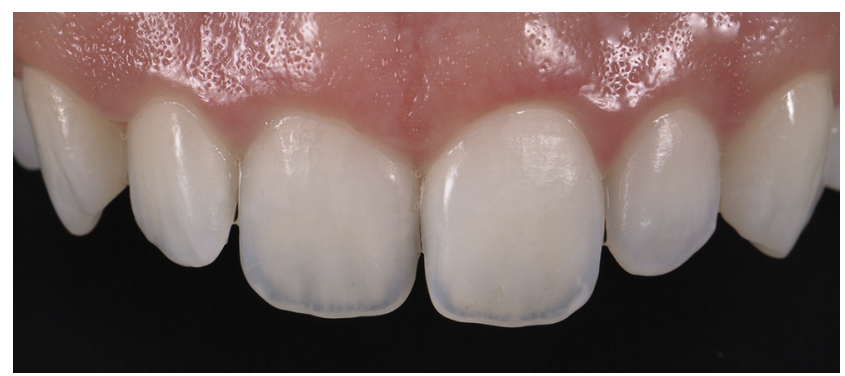

Fig. 52: The esthetic integration and natural cartographic features of the teeth are perfectly respected and conserved through this treatment, which is ultraconservative.

Fig. 52 : L'intégration esthétique et les particularités cartographiques naturelles des dents sont parfaitement respectées et conservées par l'intermédiaire de ce traitement ultraconservateur. 


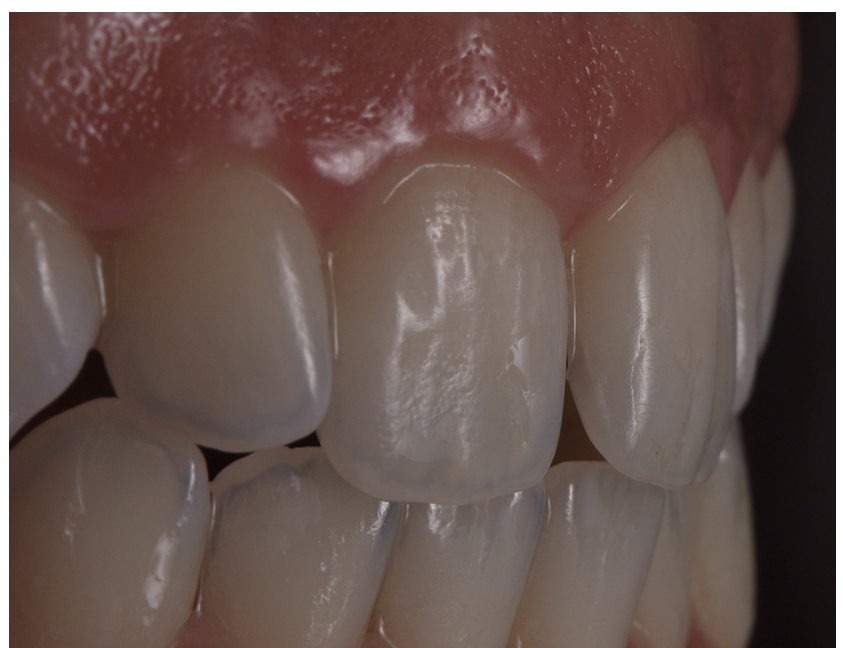

Fig. 53: Treatment of the surface macro- and micro-geography of 21 guarantees optimal integration of its composite restoration.

Fig. 53 : Le traitement de la macro- et microgéographie de surface de la 21 assure l'intégration optimale de sa restauration composite.
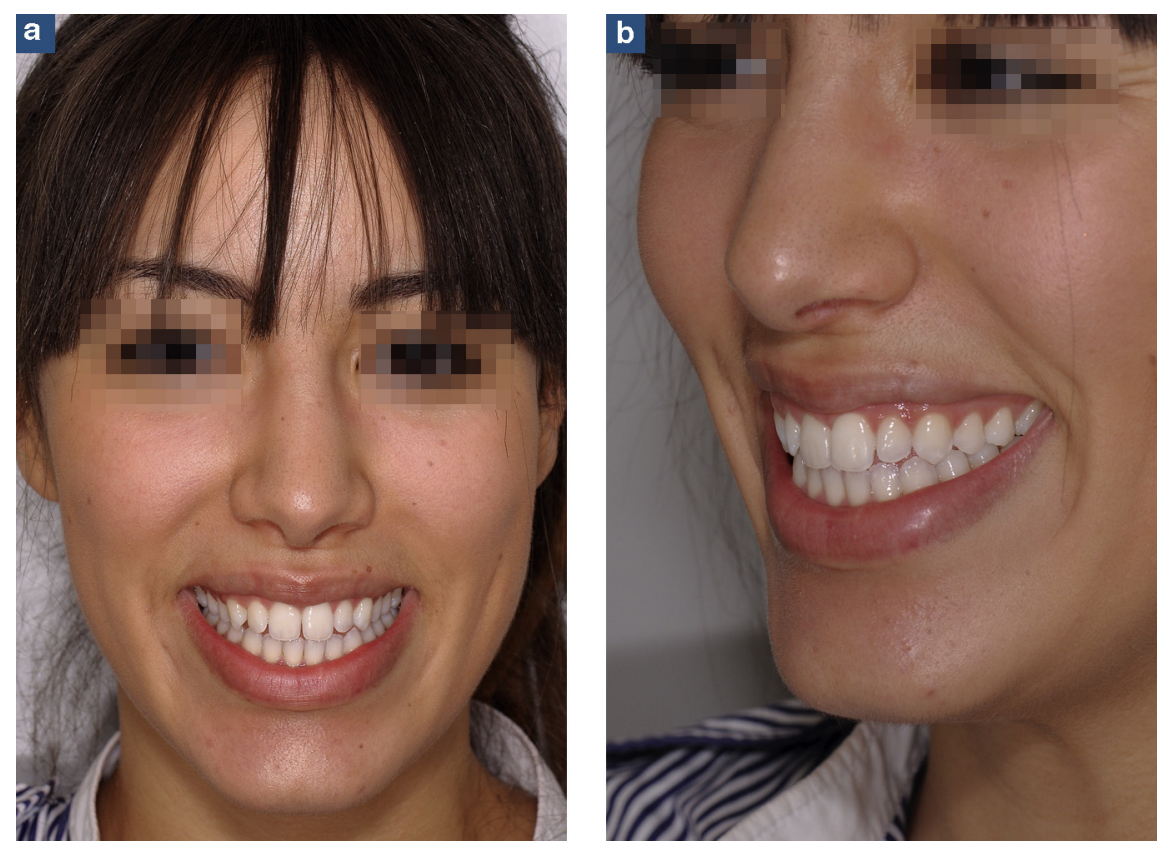

Fig. 54: a, b: the patient's smile is now more luminous and more harmonious following outpatient whitening and a single clinical session combining erosion-infiltration and composite restoration.

Fig. $54: a, b$ : le sourire de la patiente a gagné en luminosité et en harmonie après un éclaircissement ambulatoire et une seule séance clinique associant érosion/infiltration et composite de restauration. 


\section{Conclusion}

Superficial infiltration and deep infiltration are two complementary techniques. In return for a very slight mutilation of the tooth, deep infiltration makes it possible to treat all white spot lesions of the enamel, whatever their etiology or depth.

The key moment in the technique remains that of resin infiltration. Sometimes, the infiltration is performed after a large number of cycles of sandblasting/milling and erosion, but never before alcohol produces a clear optical effect.

However attractive this new deep infiltration technique may be, prudence should prevail. A significant clinical follow-up period, which we do not yet possess, remains essential before clinical indications can be defined more precisely.

\section{Disclosure of interest}

Drs Attal and Tirlet thank DMG for the support in conception of new clinical procedures.

\section{Conclusion}

L'infiltration superficielle et l'infiltration en profondeur sont 2 techniques complémentaires. L'infiltration en profondeur, en concédant une très légère mutilation de la dent, permet de traiter toutes les taches blanches de l'émail, quelle que soient leur étiologie et leur profondeur.

Le moment crucial de la technique reste celui de l'infiltration de la résine. Parfois cette infiltration se fait après un nombre important de cycles sablage/fraisage et érosion mais jamais avant que l'alcool ne produise un net effet optique.

Quel que soit l'aspect séduisant de cette nouvelle technique d'infiltration en profondeur, il faut rester prudent. Un recul clinique significatif, que nous n'avons pas encore, reste indispensable afin de permettre d'en définir plus précisément les indications cliniques.

\section{Déclaration d'intérêts}

Les Docteurs Attal et Tirlet remercient DMG pour leur soutien dans l'élaboration de nouveaux protocoles cliniques.

\section{References/Références}

1. Paris S, Meyer-Lueckel H, Mueller J, Hummel M, Kielbassa AM. Progression of sealed initial bovine enamel lesions under demineralizing conditions in vitro. Caries Res 2006;40 (2):124-9.

2. Martignon S, Ekstrand KR, Gomez J, Lara JS, Cortes A. Infiltrating/sealing proximal caries lesions: a 3-year randomized clinical trial. J Dent Res 2012;91(3):288-92.

3. Meyer-Lueckel H, Bitter K, Paris S. Randomized controlled clinical trial on proximal caries infiltration: three-year follow-up. Caries Res 2012;46(6):544-8.

4. Altarabulsi MB, Alkilzy M, Splieth CH. Clinical applicability of resin infiltration for proximal caries. Quintessence Int 2013;44(2):97-104.

5. Taher NM, Alkhamis HA, Dowaidi SM. The influence of resin infiltration system on enamel microhardness and surface roughness: an in vitro study. Saudi Dent J 2012;24(2):79-84.

6. Paris S, Schwendicke F, Seddig S, Müller WD, Dörfer C, Meyer-Lueckel H. Micro-hardness and mineral loss of enamel lesions after infiltration with various resins: influence of infiltrant composition and application frequency in vitro. J Dent 2013;41(6):543-8.

7. Yetkiner E, Wegehaupt FJ, Attin R, Attin T. Caries infiltrant combined with conventional adhesives for sealing sound enamel in vitro. Angle Orthod 2013;83(5):858-63.

8. Wiegand A, Stawarczyk B, Kolakovic M, Hämmerle CHF, Attin T, Schmidlin PR. Adhesive performance of a caries infiltrant on sound and demineralised enamel. J Dent 2011;39 (2):117-21.

9. Jia L, Stawarczyk B, Schmidlin PR, Attin T, Wiegand A. Effect of caries infiltrant application on shear bond strength of different adhesive systems to sound and demineralized enamel. J Adhes Dent 2012;14(6):569-74.

10. Attin R, Stawarczyk B, Keçik D, Knösel M, Wiechmann D, Attin T. Shear bond strength of brackets to demineralize enamel after different pretreatment methods. Angle Orthod 2012;82(1):56-61. 
11. Naidu E, Stawarczyk B, Tawakoli PN, Attin R, Attin T, Wiegand A. Shear bond strength of orthodontic resins after caries infiltrant preconditioning. Angle Orthod 2013;83(2):306-12.

12. Denis M, Atlan A, Vennat E, Tirlet G, Attal JP. White defects on enamel: diagnosis and anatomopathology: two essential factors for proper treatment (part 1). Int Orthod 2013;11 (2):139-65.

13. Paris S, Schwendicke F, Keltsch J, Dörfer C, Meyer-Lueckel H. Masking of white spot lesions by resin infiltration in vitro. J Dent 2013;41(Suppl. 5):e28-34. doi: 10.1016/j. jdent.2013.04.003 [Epub 2013 Apr 11].

14. Rocha Gomes Torres C, Borges AB, Torres LMS, Gomes IS, de Oliveira RS. Effect of caries infiltration technique and fluoride therapy on the colour masking of white spot lesions. J Dent 2011;39(3):202-7.

15. Yuan H, Li J, Chen L, Cheng L, Cannon RD, Mei L. Esthetic comparison of white-spot lesion treatment modalities using spectrometry and fluorescence. Angle Orthod 2013; [Epub ahead of print].

16. Kim S, Kim EY, Jeong TS, Kim JW. The evaluation of resin infiltration for masking labial enamel white spot lesions. Int J Paediatr Dent Br Paedodontic Soc Int Assoc Dent Child $2011 ; 21(4): 241-8$

17. Tirlet G, Attal JP. L'érosion/infiltration : une nouvelle thérapeutique pour masquer les tâches blanches. Inf Dent 2011;2-7.

18. Tirlet G, Chabouis HF, Attal JP. Infiltration, a new therapy for masking enamel white spots: a 19-month follow-up case series. Eur J Esthet Dent 2013;8(2):180-90.

19. Mun oz MA, Arana-Gordillo LA, Gomes GM, et al. Alternative esthetic management of fluorosis and hypoplasia stains: blending effect obtained with resin infiltration techniques. J Esthet Restor Dent 2013;25(1):32-9.

20. Attal JP, Denis M, Atlan A, Vennat E, Tirlet G. L'infiltration en profondeur : un nouveau concept pour le masquage des tâches blanches de l'émail. Partie 1. Inf Dent 2013;74-9.

21. Belkhir MS, Douki N. A new concept for removal of dental fluorosis stains. J Endod 1991;17 (6):288-92.

22. Ekizer A, Zorba YO, Uysal T, Ayrikcila S. Effects of demineralizaton-inhibition procedures on the bond strength of brackets bonded to demineralized enamel surface. Korean J Orthod 2012;42(1):17-22.

23. Goldberg M, Grootveld M, Lynch E. Undesirable and adverse effects of tooth-whitening products: a review. Clin Oral Investig 2009;14(1):1-10.

24. Garcia EJ, Mena-Serrano A, de Andrade AM, Reis A, Grande RH, Loguercio AD. Immediate bonding to bleached enamel treated with $10 \%$ sodium ascorbate gel: a case report with one-year follow-up. Eur J Esthet Dent 2012;7(2):154-62.

25. Ontiveros JC. Commentary: alternative esthetic management of fluorosis and hypoplasia stains: blending effect obtained with resin infiltration techniques(1). J Esthet Restor Dent 2013;25(1):40-1.

26. Knösel M, Eckstein A, Helms HJ. Durability of esthetic improvement following Icon resin infiltration of multibracket-induced white spot lesions compared with no therapy over 6 months: a single-center, split-mouth, randomized clinical trial. Am J Orthod Dentofac Orthop 2013;144(1):86-96.

27. Cohen-Carneiro F, Pascareli AM, Christino MR, Vale HF, Pontes DG. Color stability of carious incipient lesions located in enamel and treated with resin infiltration or remineralization. Int J Paediatr Dent 2013;. doi: 10.1111/ipd.12071 [Epub ahead of print]. 